\title{
Concentration-Dependent Dual Mode of Zn Action at Serotonin 5-HT1A Receptors: In Vitro and In Vivo Studies
}

\author{
Grzegorz Satala $^{1}$ - Beata Duszyńska ${ }^{1}$ - Katarzyna Stachowicz ${ }^{1}$ - Anna Rafalo ${ }^{1}$. \\ Bartlomiej Pochwat ${ }^{1}$ - Christine Luckhart ${ }^{2}$ - Paul R. Albert ${ }^{2}$ - Mireille Daigle ${ }^{2}$. \\ Kenji F. Tanaka ${ }^{3}$ - René Hen ${ }^{4}$ - Tomasz Lenda ${ }^{1}$ - Gabriel Nowak ${ }^{1}$ • \\ Andrzej J. Bojarski ${ }^{1} \cdot$ Bernadeta Szewczyk $^{1}$
}

Received: 20 August 2015 / Accepted: 29 November 2015 / Published online: 12 December 2015

(C) The Author(s) 2015. This article is published with open access at Springerlink.com

\begin{abstract}
Recent data has indicated that $\mathrm{Zn}$ can modulate serotonergic function through the $5-\mathrm{HT}_{1 \mathrm{~A}}$ receptor $(5-$ $\left.\mathrm{HT}_{1 \mathrm{~A}} \mathrm{R}\right)$; however, the exact mechanisms are unknown. In the present studies, radioligand binding assays and behavioural approaches were used to characterize the pharmacological profile of $\mathrm{Zn}$ at $5-\mathrm{HT}_{1 \mathrm{~A}} \mathrm{Rs}$ in more detail. The influence of $\mathrm{Zn}$ on agonist binding to $5-\mathrm{HT}_{1 \mathrm{~A}} \mathrm{Rs}$ stably expressed in HEK293 cells was investigated by in vitro radioligand binding methods using the agonist $\left[{ }^{3} \mathrm{H}\right]-8-\mathrm{OH}-\mathrm{DPAT}$. The in vivo effects of $\mathrm{Zn}$ were compared with those of 8-OH-DPAT in hypothermia, lower lip retraction (LLR), 5-HT behavioural syndrome and the forced swim (FST) tests. In the in vitro studies, biphasic effects, which involved allosteric potentiation of agonist binding at sub-micromolar $\mathrm{Zn}$ concentrations and inhibition at sub-millimolar $\mathrm{Zn}$ concentrations, were found. The in vivo studies showed that $\mathrm{Zn}$ did not induce LLR or elements of 5-HT behavioural syndrome but blocked such effects induced by 8-OH-DPAT. Zn decreased body temperature in rats and mice; however, $\mathrm{Zn}$ failed to induce hypothermia in the $5-\mathrm{HT}_{1 \mathrm{~A}}$ autoreceptor knockout mice. In the FST, Zn potentiated the
\end{abstract}

Bernadeta Szewczyk

szewczyk@if-pan.krakow.pl

1 Institute of Pharmacology Polish Academy of Sciences , Smetna 12, PL 31-343 Krakow, Poland

2 Ottawa Hospital Research Institute, UOttawa Brain and Mind Research Institute , 451 Smyth Road \#2464, Ottawa, ON K1H-8M5, Canada

3 Department of Neuropsychiatry, School of Medicine, Keio University, Tokyo 160-8582, Japan

4 Department of Psychiatry, Columbia University Medical Center and Research Foundation for Mental Hygiene, New York State Psychiatric Institute, New York, NY 10032, USA effect of 8-OH-DPAT. However, in the FST performed with the $5-\mathrm{HT}_{1 \mathrm{~A}}$ autoreceptor knockout mice, the anti-immobility effect of $\mathrm{Zn}$ was partially blocked. Both the binding and behavioural studies suggest a concentration-dependent dual mechanism of $\mathrm{Zn}$ action at $5-\mathrm{HT}_{1 \mathrm{~A}} \mathrm{Rs}$, with potentiation at low dose and inhibition at high dose. Moreover, the in vivo studies indicate that $\mathrm{Zn}$ can modulate both presynaptic and postsynaptic 5-HT ${ }_{1 \mathrm{~A}} \mathrm{Rs}$; however, Zn's effects at presynaptic receptors seem to be more potent.

Keywords $\mathrm{Zn} \cdot$ Serotonin $\cdot 5-\mathrm{HT}_{1 \mathrm{~A}} \cdot$ Autoreceptor . Depression $\cdot$ Binding $\cdot$ Behavioural studies

$\begin{array}{ll}\text { Abbreviations } \\ \text { DOI } & ( \pm) \text {-2,5-Dimethoxy-4-iodoamphetamine } \\ \text { FBP } & \text { Flat body posture } \\ \text { FST } & \text { Forced swim test } \\ \text { FT } & \text { Forepaw treading } \\ \text { GalR1 } & \text { Galanin 1 receptor } \\ \text { HEK293 } & \text { Human embryonic kidney 293 } \\ \text { 5-HT }{ }_{1 \mathrm{~A}} \mathrm{R} & \text { 5-HT }{ }_{1 \mathrm{~A}} \text { receptor } \\ \text { 5-HT } & \text { 5-Hydroxytryptamine (serotonin) } \\ \text { 5-MeO- } & \text { 5-Methoxy-N,N-dimethyltryptamine } \\ \text { DMT } & \\ \text { 8-OH- } & \text { 8-Hydroxy-2-(di-n-propylamino)tetralin } \\ \text { DPAT } & \\ \text { LLR } & \text { Lower lip retraction } \\ \text { mCPP } & \text { 1-(3-Chlorophenyl)piperazine } \\ \text { pCPA } & \text { p-Chlorophenylalanine } \\ \text { PFC } & \text { Prefrontal cortex } \\ \text { WAY- } & \text { (S)-N-tert-Butyl-3-(4-(2-methoxyphenyl)- } \\ \text { 100135 } & \text { piperazin-1-yl)-2-phenylpropanamide } \\ & \text { dihydrochloride }\end{array}$


WAY- $\quad$ N-[2[4-(2-methoxyphenyl)-1-

100635 piperazinyl] ethyl]-N-(2-

pyridyl)cyclohexanecarboxamide

\section{Introduction}

Zinc ( $\mathrm{Zn})$ is an essential trace element that is required for proper brain function [1]. Zn modulates neuronal excitability, plays an important role in synaptic plasticity and can function as a signalling molecule $[2,3]$. Recent data have indicated that disturbances in $\mathrm{Zn}$ homeostasis are involved in the aetiology of some neurological disorders. Several studies, including both preclinical and clinical studies, showed that $Z n$ deficiency leads to the development of depression [4-6] and that $\mathrm{Zn}$ supplementation improves the effectiveness of standard antidepressant treatment $[7,8]$. One of the possible mechanisms involved in $\mathrm{Zn}$ antidepressant activity is the modulation of the serotonergic system through $5-\mathrm{HT}_{1 \mathrm{~A}}$ and $5-\mathrm{HT}_{2 \mathrm{~A}}$ receptors $[9$, 10]. $\mathrm{Zn}$ was found to enhance the effect of citalopram and fluoxetine in the forced swim test (FST) in mice, and pretreatment with an inhibitor of serotonin synthesis, pchlorophenylalanine (pCPA), blocked the antidepressant-like effect observed in the FST [10]. Moreover, the fact that rats show an increase in the swimming but not the climbing parameter in the FST following $\mathrm{Zn}$ administration indicates (according to the observation of Detke et al. [11]) the involvement of the serotonin pathway in the effects of $\mathrm{Zn}$ in the FST [10]. Additionally, it was found that the antidepressant-like effect of $\mathrm{Zn}$ in the FST in mice was blocked by the $5-\mathrm{HT}_{1 \mathrm{~A}} \mathrm{R}$ antagonist WAY-100635, which suggested that the modulation of the serotonergic system by $\mathrm{Zn}$ is mediated mostly through the $5-\mathrm{HT}_{1 \mathrm{~A}} \mathrm{R}[10]$.

Further evidence for the postulated direct link between $\mathrm{Zn}$ and $5-\mathrm{HT}_{1 \mathrm{~A}} \mathrm{R}$ were recently provided by Tena-Campos et al. [12] who showed the impact of $\mathrm{Zn}$ homeostasis on the balance between monomers/heterodimers of $5-\mathrm{HT}_{1 \mathrm{~A}}$ and galanin 1 receptor (GalR1). The latter protein was indicated as being involved in major depressive disorder by modulating 5$\mathrm{HT}_{1 \mathrm{~A}}$ functionality via specific heterodimerization process [12].

The direct modulatory effect of $\mathrm{Zn}$ at the $5-\mathrm{HT}_{1 \mathrm{~A}} \mathrm{R}$ was also reported by Barrondo and Salles, who described negative allosteric modulatory properties of $\mathrm{Zn}$ ions against antagonist $\left(\left[{ }^{3} \mathrm{H}\right]-\right.$ WAY-100635) and agonist $\left(\left[{ }^{3} \mathrm{H}\right]-8-\mathrm{OH}-\mathrm{DPAT}\right)$ binding at $5-\mathrm{HT}_{1 \mathrm{~A}} \mathrm{Rs}$ in cortical membranes isolated from the rat brain [13]. It should be noted, however, that the changes observed for $\left[{ }^{3} \mathrm{H}\right]-8-\mathrm{OH}-\mathrm{DPAT}$ (i.e. a decrease of dissociation constant $\left(K_{D}\right)$ and $B_{\max }$ values were demonstrated through saturation experiments only and were complex and difficult to interpret. Moreover, although studies using native tissue have strong biological significance, membranes prepared from rat cerebral cortex contain other receptors that can be targeted by $\left[{ }^{3} \mathrm{H}\right]-8-$
OH-DPAT (i.e. serotonin $5-\mathrm{HT}_{7}$ receptors and $\alpha-2$ adrenergic receptors) [14, 15], which might create an additional level of complexity in the interactions of $\mathrm{Zn}$ at $5-\mathrm{HT}_{1 \mathrm{~A}} \mathrm{Rs}$. As allosteric modulation is strongly probe-dependent [16], evaluation of the effects of $\mathrm{Zn}$ on agonist binding is of primary importance to its action observed in vivo. Thus, we performed in vitro radioligand experiments to gain further mechanistic insight into the nature of $\mathrm{Zn}$ interactions at $5-\mathrm{HT}_{1 \mathrm{~A}} \mathrm{Rs}$. In the present study, HEK293 cells expressing $5-\mathrm{HT}_{1 \mathrm{~A}}\left(5-\mathrm{HT}_{1 \mathrm{~A}}\right)$ receptors were used, which provides a homogeneous system to study effects solely attributable to the $5-\mathrm{HT}_{1 \mathrm{~A}} \mathrm{R}$ subtype. The influence of $\mathrm{Zn}$ ions on agonist binding was investigated by saturation, competition and both association and dissociation kinetic studies using $\left[{ }^{3} \mathrm{H}\right]-8-\mathrm{OH}-\mathrm{DPAT}$, a $5-\mathrm{HT}_{1 \mathrm{~A}} \mathrm{R}$ agonist.

Due their localization, neuronal $5-\mathrm{HT}_{1 \mathrm{~A}} \mathrm{Rs}$ are divided into two different classes: the 5- $\mathrm{HT}_{1 \mathrm{~A}}$ autoreceptors located on the soma and dendrites of serotonergic neurons in the raphe nucleus and the heteroreceptors expressed postsynaptically in the prefrontal cortex (PFC), amygdala and hippocampus [17, 18]. The activation of $5-\mathrm{HT}_{1 \mathrm{~A}} \mathrm{R}$ has been shown to induce a number of behavioural responses, including lower lip retraction (LLR), flat body posture (FBP), forepaw treading (FT), and a decrease in body temperature [19-23]. The ability of compounds to induce or block these behaviours is commonly used to differentiate and characterize their activity at pre- or postsynaptic 5-HT ${ }_{1 \mathrm{~A}} \mathrm{Rs}$. Therefore, in addition to the binding assays, we assessed the ability of $Z n$ to produce LLR, FBP and FT in rats. We also studied both the capacity of $\mathrm{Zn}$ to induce hypothermia and the activity of Zn in the FST in rats as well as in wild-type and $5-\mathrm{HT}_{1 \mathrm{~A}}$ autoreceptor knockout mice.

\section{Methods}

\section{Receptor Binding Studies}

Drugs

$\left[{ }^{3} \mathrm{H}\right]-8-\mathrm{OH}-\mathrm{DPAT}(135.2 \mathrm{Ci} / \mathrm{mmol})$ was purchased from PerkinElmer and (R)-(+)-8-OH-DPAT, 5-HT and $\mathrm{ZnCl}_{2}$ were obtained from Sigma-Aldrich.

\section{Expression of the Gene for the Human 5-HT $T_{1 A} R$}

The full-length human $5 \mathrm{HTR}_{1 \mathrm{~A}}$ complementary DNA (cDNA), which was cloned into the mammalian expression vector pcDNA3.1(+), was obtained from the Missouri S\&T cDNA Resource Center (www.cdna.org). The receptor cDNA was stably transfected into human embryonic kidney cells (HEK293, ATCC) with the use of Lipofectamine 2000 (Invitrogen). A clone yielding a high expression level of 5$\mathrm{HT}_{1 \mathrm{~A}} \mathrm{R}$ was selected during preliminary experiments, including RT-PCR and Western blot analysis. 


\section{Cell Culture and Preparation of Cell Membranes}

HEK293 cells with stable expression of $5-\mathrm{HT}_{1 \mathrm{~A}} \mathrm{R}$ were maintained at $37{ }^{\circ} \mathrm{C}$ in a humidified atmosphere with $5 \% \mathrm{CO}_{2}$ and were grown in Dulbecco's Modified Eagle Medium (Lonza Ltd.) containing $10 \%$ dialysed foetal bovine serum (Lonza Ltd.) and $500 \mu \mathrm{g} / \mathrm{ml} \mathrm{G} 418$ sulphate (Sigma-Aldrich). For membranes preparations, the cells were subcultured in $150 \mathrm{~cm}^{2}$ flasks, grown to $90 \%$ confluence, washed twice with phosphate buffered saline (PBS) prewarmed to $37{ }^{\circ} \mathrm{C}$ and pelleted by centrifugation ( $200 \mathrm{~g}$ for $5 \mathrm{~min}$ ) in PBS containing $0.1 \mathrm{mM}$ EDTA and $1 \mathrm{mM}$ dithiothreitol. Prior to membrane preparation, the pellets were stored at $-80{ }^{\circ} \mathrm{C}$.

\section{Preparation of Membranes for Radioligand Binding Assays}

Cell pellets were thawed and homogenized in 20 volumes of $50 \mathrm{mM}$ Tris- $\mathrm{HCl}$ buffer ( $\mathrm{pH}$ 7.7) containing $0.1 \mathrm{mM}$ EDTA and $10 \mathrm{mM} \mathrm{MgCl} 2$, using an Ultra Turrax tissue homogenizer. The pellets were then centrifuged twice at $35,000 \mathrm{~g}$ for $20 \mathrm{~min}$ at $4{ }^{\circ} \mathrm{C}$, with incubation for $15 \mathrm{~min}$ at $37{ }^{\circ} \mathrm{C}$ in between centrifugations. Membranes were aliquoted in tubes. Membrane protein concentrations were determined using the Pierce ${ }^{\mathrm{TM}}$ Coomassie (Bradford) Protein Assay Kit, with bovine serum albumin (BSA) as a standard.

\section{Radioligand Binding Assays}

$\left[{ }^{3} \mathrm{H}\right]-8-\mathrm{OH}-\mathrm{DPAT}$ was used as a selective 5 - $\mathrm{HT}_{1 \mathrm{~A}} \mathrm{R}$ agonist. The affinity $\left(K_{\mathrm{D}}\right)$ and maximal number of binding sites $\left(B_{\max }\right)$ were measured by saturation binding experiments over a radioligand concentration range of $0.1-14 \mathrm{nM}$. The affinity shift was determined by measuring the $K_{\mathrm{D}}$ obtained in saturation binding assays performed in the absence and presence of six concentrations of $\mathrm{Zn}(0.01-5 \mathrm{mM})$. Competition studies were performed with $2.5 \mathrm{nM}$ of $\left[{ }^{3} \mathrm{H}\right]-8-\mathrm{OH}-$ DPAT in the presence of various concentrations of orthosteric agonist serotonin in the absence and presence of $\mathrm{Zn}$ at two concentrations (10 and $500 \mu \mathrm{M}$ ). Nonspecific binding was estimated in the presence of $10 \mu \mathrm{M}$ 5-HT. The incubation buffer consisted of $50 \mathrm{mM}$ Tris- $\mathrm{HCl}$ (pH 7.7), $10 \mathrm{mM} \mathrm{MgCl} 2,10 \mathrm{mM}$ pargyline and $0.1 \%$ ascorbic acid. Radioligand binding assays were performed by incubating $30 \mu \mathrm{g}$ of protein of the membrane suspension in 96-well microtitre plates for $60 \mathrm{~min}$ at room temperature with shaking, in a total volume of $200 \mu \mathrm{l}$. The binding reactions were stopped by filtration through $\mathrm{GF} / \mathrm{C}$ Unifilter plates using a harvester (PerkinElmer). The plate filters were dried, and $20 \mu \mathrm{l}$ of Ultima Gold MV (PerkinElmer) was added. Radioactivity was measured using a MicroBeta TriLux counter (PerkinElmer).
Association and Dissociation Assays

Association and dissociation rate kinetic assays were performed at room temperature using the same buffer conditions described for the equilibrium binding assays and $2.5 \mathrm{nM}\left[{ }^{3} \mathrm{H}\right]-$ 8-OH-DPAT. Non-specific binding was defined by the addition of $10 \mu \mathrm{M}$ serotonin. The amount of radioligand bound to the receptor was measured at different time intervals during a total incubation of $60 \mathrm{~min}$ in the absence or presence of 10 and $500 \mu \mathrm{M} \mathrm{ZnCl}_{2}$. For the dissociation assay, after incubating the membranes with radioligand for $60 \mathrm{~min}$ to achieve equilibrium, serotonin $(10 \mu \mathrm{M})$, either alone or together with 10 or $500 \mu \mathrm{M}$ of $\mathrm{ZnCl}_{2}$, was added, and the specifically bound radioligand was measured after incubations of different durations (from 0 to $60 \mathrm{~min}$ ), which were terminated by rapid filtration.

\section{Data Analysis}

All experiments were performed in triplicate, and the results were obtained from at least three independent experiments. The data are expressed as the mean \pm S.D. (standard deviation). The experimental data were analysed using GraphPad Prism 5.1 for Windows (GraphPad Software, San Diego California USA, www.graphpad.com). Analysis of the saturation binding data with respect to allosteric interactions was performed with the use of equation (1) [24]:

$p K_{\text {App }}=-\log \left([B]+10^{\log K_{B}}\right)+\log \left(\alpha[B]+10^{\log K_{B}}\right)-\log d$

where $K_{\mathrm{App}}$ is the apparent equilibrium dissociation constant of radioligand $A\left(\left[{ }^{3} \mathrm{H}\right]-8-\mathrm{OH}-\mathrm{DPAT}\right)$ observed in the presence of modulator B $\left(\mathrm{ZnCl}_{2}\right) ; K_{A}$ and $K_{B}$ are the equilibrium dissociation constants of the radioligand and allosteric modulator, respectively; $\log d$ is a constant representing the logarithm of the quotient of $K_{A}$ and $\alpha$; and $\alpha$ defines the cooperativity factor, the magnitude by which the equilibrium dissociation constant of either ligand for its site on the receptor is modified by the concomitant presence of the other ligand. Values of $\alpha$ less than 1 (but greater than zero) denote negative cooperativity, values greater than 1 denote positive cooperativity and values not significantly different from 1 indicate neutral cooperativity.

Bell-shaped concentration-response curves were fit to a special model [16], based on equation (2):

$$
\rho_{A}=\frac{\frac{[A]}{K_{A}}\left(1+\frac{\alpha^{\prime}[B]}{K_{B 2}}\right)}{\frac{[A]}{K_{A}}\left(1+\frac{\alpha^{\prime}[B]}{K_{B 2}}\right)+1+\frac{[B]}{K_{B 1}}+\frac{[B]}{K_{B 2}}\left(1+\frac{\beta[B]}{K_{B 1}}\right)}
$$

where $\rho_{\mathrm{A}}$ denotes the fractional receptor occupancy by the orthosteric ligand; $[A]$ and $[B]$ are the concentrations of 
$\left[{ }^{3} \mathrm{H}\right]-8-\mathrm{OH}-\mathrm{DPAT}$ and $\mathrm{ZnCl}_{2}$, respectively; $K_{A}, K_{B 1}$, and $K_{B 2}$ denote equilibrium dissociation constants; the subscript ' 1 ' refers to the binding of $\mathrm{B}$ to the orthosteric site; the subscript ' 2 ' refers to the binding of $\mathrm{B}$ to the allosteric site; the cooperativity factor $\alpha^{\prime}$ denotes the interaction between $B$ and $A$; and $\beta$ denotes the interaction between the two molecules of $B$.

The experimental data were fit to one-site and two-site models to determine the best fit. The statistical significance of differences between the means was evaluated by Student's $t$ test. The level of significance was set at $p<0.05$.

\section{Behavioural Studies}

\section{Animals and Housing}

The experiments were performed on male Albino Swiss mice (23-25 g) and Sprague Dawley rats (200-250 g) from Charles River, Germany as well as TPH2-Cre-ER ${ }^{\mathrm{T} 2} \mathrm{x}$ flx $-5-\mathrm{HT}_{1 \mathrm{~A}}$-flxYFP mice from Jackson Labs, Bangor ME and the Hen lab, respectively. The animals were kept under standard laboratory conditions with respect to lighting (light phase 7:00-19:00) and temperature $\left(19-21^{\circ} \mathrm{C}\right)$. Food and water were freely available. Each experimental group consisted of eight to ten animals. All of the animals were experimentally naive and were used only once in each test. The experiments were performed during the light period (9:00-14:00 h). All of the procedures were conducted according to the guidelines of the National Institutes of Health Animal Care and Use Committee and were approved by the Ethics Committees of the Institute of Pharmacology, Polish Academy of Sciences in Krakow and the Animal Care Committee, University of Ottawa.

\section{Drug Administration}

$\mathrm{Zn}$ (all doses refer to $\mathrm{mg} \mathrm{Zn} / \mathrm{kg}$ ) was given as either $\mathrm{Zn}$ hydroaspartate (Farmapol, Poland) or Zn chloride (SigmaAldrich) and was dissolved in $0.9 \% \mathrm{NaCl}$ and administered intraperitoneally (i.p.). 8-OH-DPAT and WAY-100635 were dissolved in aqua pro-injection and were administered subcutaneously (s.c.). Controls were treated with the appropriate diluent, which was indicated as VEH on the graphs and in the tables.

\section{Presynaptic 5-HT ${ }_{1 A} R$ Knockout Mice}

A conditional knockout approach was used to eliminate the 5$\mathrm{HT}_{1 \mathrm{~A}} \mathrm{R}$ in the raphe nuclei in adult mice. To create the conditional 5- $\mathrm{HT}_{1 \mathrm{~A}} \mathrm{R}$ knockout mice, a TPH2-Cre-ER ${ }^{\mathrm{T} 2}$ mouse line was crossed with a flx-5-HT $1 \mathrm{~A}$-YFP mouse line. The TPH2Cre-ER ${ }^{\mathrm{T} 2}$ confers specificity such that only serotonin neurons, which express tryptophan hydroxylase 2 (TPH2), can express Cre recombinase to knockout the $5-\mathrm{HT}_{1 \mathrm{~A}} \mathrm{R}$ gene and allow for
GFP expression [25]. Once the mice reached adulthood (approximately 5-6 postnatal weeks), tamoxifen $(180 \mathrm{mg} / \mathrm{kg})$ was injected i.p. every day for five consecutive days (the tamoxifen binds to the $\mathrm{ER}^{\mathrm{T} 2}$ domain and enables Cre to enter the nucleus where it can excise the 5- $\mathrm{HT}_{1 \mathrm{~A}} \mathrm{R}$ gene, allowing for YFP expression as a marker of recombination). The mice were then left undisturbed for at least 14 days to allow for recombination and the turnover of endogenous $5-\mathrm{HT}_{1 \mathrm{~A}} \mathrm{Rs}$.

\section{Lower Lip Retraction}

LLR was assessed according to the method described by Berendsen et al., [20]. The rats were individually placed in cages $(30 \times 25 \times 25 \mathrm{~cm})$ and were scored three times, 15,30 and 45 min after the administration of $\mathrm{Zn}$ as follows: $0=$ lower incisors not visible, $0.5=$ partly visible and $1=$ completely visible. $\mathrm{Zn}$ was administered at doses of 2 and $5 \mathrm{mg} \mathrm{Zn} / \mathrm{kg}$ (given as $\mathrm{Zn}$ hydroaspartate, Farmapol, Poland). The maximum total score was $3 /$ rat. In addition, the effects of $\mathrm{Zn}$ and WAY$100635(0.1 \mathrm{mg} / \mathrm{kg}$; Sigma $)$ on the LLR induced by $8-\mathrm{OH}-$ DPAT ( $1 \mathrm{mg} / \mathrm{kg}$; Sigma) were tested. Zn and WAY-100635 were administered $45 \mathrm{~min}$ before 8-OH-DPAT, and the animals were scored 15,30 and 45 min after the 8-OH-DPAT administration.

\section{Behavioural Syndrome}

The experiments were conducted according to previously published procedure [26], with a modification to the ranked intensity scale. Briefly, the rats were individually placed in cages $(30 \times 25 \times 25 \mathrm{~cm}) 5 \mathrm{~min}$ before tested compounds were injected. Forepaw treading (FT) and flat body posture (FBP) were scored using a ranked intensity scale, where $0=$ absent, $1=$ equivocal and $2=$ present. The $\mathrm{Zn}(2,5,7.5$ and $11.5 \mathrm{mg}$ $\mathrm{Zn} / \mathrm{kg}$, given as a $\mathrm{Zn}$ hydroaspartate)-induced behavioural syndrome was scored for each animal 3, 6, 9, 12 and $15 \mathrm{~min}$ after the $\mathrm{Zn}$ treatment. Each observation session lasted for $45 \mathrm{~s}$. The maximum score, which was summed over 5 observation periods, was 10 for each symptom/rat. The effect of $\mathrm{Zn}$ on the behavioural syndrome induced by $8-\mathrm{OH}-\mathrm{DPAT}$ ( $5 \mathrm{mg} / \mathrm{kg}$ ) was scored using the same scale. Zn was administered $60 \mathrm{~min}$ before 8-OH-DPAT, and the animals were scored 3, 6, 9, 12 and $15 \mathrm{~min}$ after the 8-OH-DPAT treatment.

\section{Body Temperature in Mice and Rats}

The effects of $\mathrm{Zn}(2,5,7.5$ and $11.5 \mathrm{mg} \mathrm{Zn} / \mathrm{kg}$ for rats and 2 and $5 \mathrm{mg} / \mathrm{kg}$ for mice, given as a $\mathrm{Zn}$ hydroaspartate), 8-OHDPAT $(5 \mathrm{mg} / \mathrm{kg})$ and WAY-100635 $(0.1 \mathrm{mg} / \mathrm{kg})$ on rectal body temperature were recorded 30 and $60 \mathrm{~min}$ after their acute administration. The results were expressed as a change in body temperature with respect to the basal body temperature, which was measured at the beginning of the experiments. 
Body Temperature in 5-HT ${ }_{1 A}$ Autoreceptor KO Mice

A separate experiment was performed to measure the effect of $\mathrm{Zn}$ on rectal body temperature in wild-type and 5- $\mathrm{HT}_{1 \mathrm{~A}}$ autoreceptor KO mice; however, in this experiment, only the higher dose of Zn (5 mg Zn/kg; Zn chloride, Sigma) was used.

\section{Forced Swim Test (FST)}

Rats The test was carried out according to the method described previously [10]. On day one of the experiment, the animals were individually placed in plexiglass cylinders (40 $\mathrm{cm}$ in height, $18 \mathrm{~cm}$ in diameter), containing $25 \mathrm{~cm}$ of water maintained at $24-25^{\circ} \mathrm{C}$ for a 15 -min habituation period. After the rats were removed from the water, they were again placed in their home cages. On the second day, the rats were again placed in the cylinders, and the total duration of immobility was measured for a 5 -min test period. $\mathrm{Zn}$ ( 1 or $2 \mathrm{mg} \mathrm{Zn/}$ $\mathrm{kg}$, given as $\mathrm{Zn}$ hydroaspartate) and 8-OH-DPAT (0.1 or $0.3 \mathrm{mg} / \mathrm{kg}$ ) were administered alone or jointly $30 \mathrm{~min}$ before the test. WAY-100635 $(0.1 \mathrm{mg} / \mathrm{kg})$ was administered $15 \mathrm{~min}$ before the $\mathrm{Zn}$ treatment.

5-HT ${ }_{1 A}$ Autoreceptor KO Mice The behaviour of the mice in the water was recorded using a video camera. The test was performed under red lighting. The cylinder was filled with almost 41 of water, to a depth that exceeded the distance to which the tail could extend, so the mouse could not balance on its tail at the bottom of the cylinder. The top of the cylinder was $9 \mathrm{~cm}$ above the surface of the water. The mice were placed in the individual glass cylinder $(22 \mathrm{~cm}$ diameter $\times 37 \mathrm{~cm} \mathrm{high})$ for a standard 6-min test; however, the total duration of immobility from the last $4 \mathrm{~min}$ of the test was analysed. In this test, only one dose of $\mathrm{Zn}-5 \mathrm{mg} \mathrm{Zn} / \mathrm{kg}$ (given as a $\mathrm{Zn}$ chloride)—was administered $30 \mathrm{~min}$ before the test.

\section{Data Analysis}

One-way ANOVA followed by Dunnett's multiple comparison test (LLR, FBP, FT and FST) or Student's $t$ test (FST and body temperature in wild-type and $5-\mathrm{HT}_{1 \mathrm{~A}}$ autoreceptor $\mathrm{KO}$ mice) was used, and $p<0.05$ was considered significant.

\section{Results}

\section{Receptor Binding Studies}

The binding of $\left[{ }^{3} \mathrm{H}\right]-8-\mathrm{OH}-\mathrm{DPAT}$ to $5-\mathrm{HT}_{1 \mathrm{~A}}$ Rs was saturable, yielding an equilibrium constant of $K_{D}=2.9 \pm 0.1 \mathrm{nM}(n=4)$ and a maximal receptor binding of $B_{\max }=4.5 \pm 0.3 \mathrm{pM} / \mathrm{mg}$ prot. Saturation isotherms obtained for six increasing concentrations of $\mathrm{Zn}(10 \mu \mathrm{M}-5 \mathrm{mM})$ revealed a decrease in radioligand binding (Fig. 1a). The $K_{D}$ values for $\left[{ }^{3} \mathrm{H}\right]-8-\mathrm{OH}-$ DPAT increased from $5 \mathrm{nM}$ at $10 \mu \mathrm{M}$ of $\mathrm{Zn}$ to $9.6 \mathrm{nM}$ at $5 \mathrm{mM}$ of $Z n$ relative to the $K_{D}$ obtained for $\left[{ }^{3} \mathrm{H}\right]-8-\mathrm{OH}-\mathrm{DPAT}$ without $\mathrm{Zn}$ (Table 1). At the same time, unusual changes in $B_{\max }$ values were observed. $\mathrm{Zn}$ at $10 \mu \mathrm{M}$ caused an increase in specific binding $\left(B_{\max }=5.8 \pm 0.7 \mathrm{pM} / \mathrm{mg}\right.$ prot. $), \mathrm{Zn}$ at 0.5 and $1 \mathrm{mM}$ recovered the control values $(4.7 \pm 0.7$ and $4.0 \pm 0.6 \mathrm{pM} /$ $\mathrm{mg}$ prot., respectively), and the two highest concentrations of $\mathrm{Zn}(2.5$ and $5 \mathrm{mM})$ significantly decreased $B_{\max }$ values $(3.1 \pm$ 1.0 and $2.2 \pm 0.8 \mathrm{pM} / \mathrm{mg}$ prot., respectively).

The data derived from the saturation experiments were fit using nonlinear regression according to equation 1 (Fig. 1b), and the calculated value of the cooperativity factor $(\alpha=0.37)$ indicated negative modulation between the binding of $\mathrm{Zn}$ and the agonist radioligand. This is generally consistent with the results described by Barrondo and Salles for rat cortical membranes, except that increased $B_{\max }$ values at lower $\mathrm{Zn}$ concentrations were not observed in their saturation studies [13].

Next, a Zn titration curve against a single, fixed concentration of $\left[{ }^{3} \mathrm{H}\right]-\mathrm{OH}-\mathrm{DPAT}(2.5 \mathrm{nM})$ was evaluated in competition-like experiments. As observed in Fig. 2a, a bellshaped binding curve was obtained, with an $\sim 25 \%$ increase of $\left[{ }^{3} \mathrm{H}\right]-8-\mathrm{OH}-\mathrm{DPAT}$ specific binding at $10 \mu \mathrm{M}$ of $\mathrm{Zn}$ and subsequent inhibition at $>100 \mu \mathrm{M}$. This type of binding is characteristic of ligands exhibiting some degree of allosteric enhancement; therefore, the classic model of negative cooperativity is not a complete description of the action of $\mathrm{Zn}$ ions on agonist binding at $5-\mathrm{HT}_{1 \mathrm{~A}} \mathrm{Rs}$. Thus, it was interesting to check the influence of $\mathrm{Zn}$ ions on serotonin (as an endogenous orthosteric agonist) in displacement experiments in the absence and presence of 10 and $500 \mu \mathrm{M}$ of Zn. The 5HT tested alone completely inhibited $\left[{ }^{3} \mathrm{H}\right]-8-\mathrm{OH}-\mathrm{DPAT}$ binding at $5-\mathrm{HT}_{1 \mathrm{~A}} \mathrm{Rs}$, with a $K_{i}$ of $8.7 \pm 0.6 \mathrm{nM}$; addition of $10 \mu \mathrm{M}$ of $\mathrm{Zn}$ ions caused a small but significant reduction of $\mathrm{K}_{\mathrm{i}}$ value for 5-HT ( $K_{i}=5.4 \pm 0.2 \mathrm{nM}, p<0.05, F$ test), while at higher $\mathrm{Zn}$ concentrations the affinity of 5-HT remained unchanged $\left(K_{i}=\right.$ $8.1 \pm 0.6 \mathrm{nM}$ ). Figure $2 \mathrm{~b}$ shows a representative set of inhibition curves of $\left[{ }^{3} \mathrm{H}\right] 8$-OH-DPAT for 5 -HT obtained in the absence and presence of $\mathrm{Zn}$ ions.

\section{Kinetic Studies}

It is well known that allosteric modulators may increase or decrease the association and/or dissociation rates of an orthosteric ligand at its binding site in a way that enhancers increase the association rate and/or decrease the dissociation rate, whereas negative allosteric modulators act in the opposite way. On the other hand, competitive orthosteric ligands can influence the association rate by increasing the time needed for the radioligand to reach equilibrium, but do not change the dissociation rate [27].

Taking into account the complex mechanism of $\mathrm{Zn}$ influence on agonist binding, dissociation and association (see 

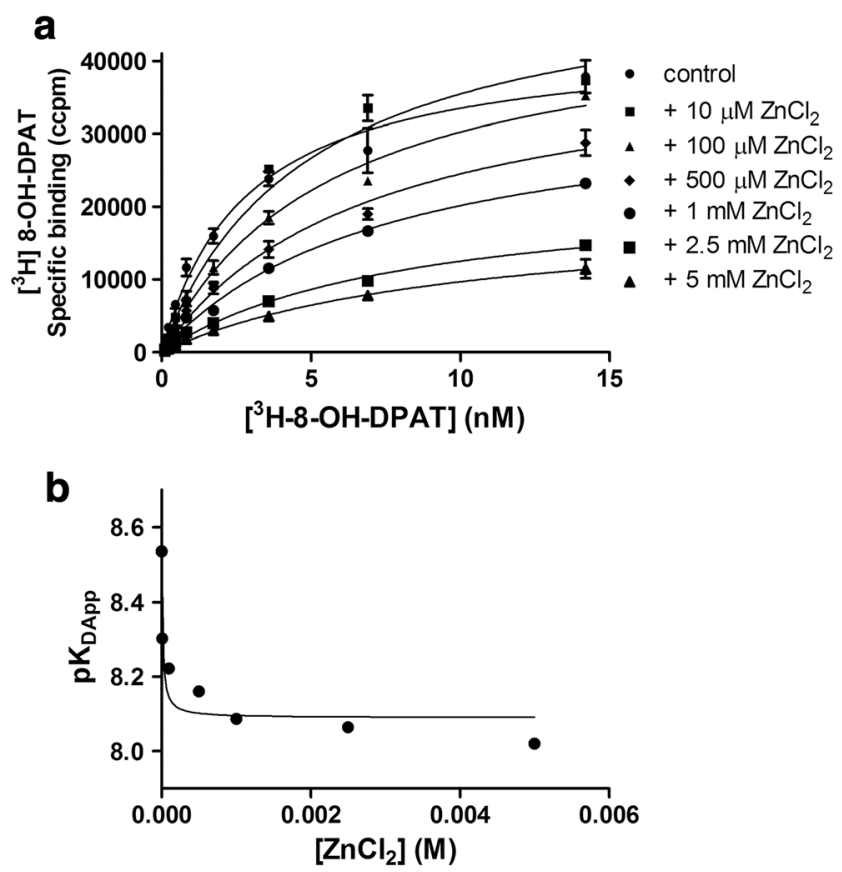

Fig. 1 Effect of increasing concentrations of $\mathrm{Zn}$ on the saturation binding of $\left[{ }^{3} \mathrm{H}\right]-8-\mathrm{OH}-\mathrm{DPAT}$ in $5-\mathrm{HT}_{1 \mathrm{~A}}$ receptor-expressing HEK293 cells. a Representative set of radioligand saturation binding curves obtained in the absence and presence of $\mathrm{Zn}$. b Nonlinear regression analysis of the saturation data according to equation 1

Fig. 3) rates were measured in kinetic assays; the values of kinetic parameters are listed in Table 2.

In the absence of $\mathrm{Zn}$, the dissociation rate for $\left[{ }^{3} \mathrm{H}\right]-8$ OH-DPAT at $5-\mathrm{HT}_{1 \mathrm{~A}} \mathrm{Rs}$ was biphasic, and it remained biphasic at high $\mathrm{Zn}$ concentration, but both phases were significantly reduced without affecting the proportion of each state. However, the presence of a low concentration of $\mathrm{Zn}$ led to the disappearance of the fast radioligand dissociation rate, and the kinetics of $\left[{ }^{3} \mathrm{H}\right]$ 8-OH-DPAT became monophasic. These results suggest that $\mathrm{Zn}$ modifies receptor conformation, reducing agonist radioligand dissociation, which is in line with the enhancing effects exerted by $\mathrm{Zn}$ in the competition-like experiments.

As detailed in Table 2, $\left[{ }^{3} \mathrm{H}\right]-8-\mathrm{OH}-\mathrm{DPAT}(2.5 \mathrm{nM})$ binds at $5-\mathrm{HT}_{1 \mathrm{~A}} \mathrm{Rs}$ with an association rate constant $\left(\mathrm{k}_{\mathrm{on}}\right)$ of $3.4 \pm 0.4 \times 10^{8} \mathrm{M}^{-1} \mathrm{~min}^{-1}$. In the presence of $10 \mu \mathrm{M}$ of $\mathrm{Zn}$ ions, a small increase in the association rate was observed, while at a higher concentration $(500 \mu \mathrm{M}), \mathrm{Zn}$ had no effect on the $\mathrm{k}_{\text {on }}$ values. a
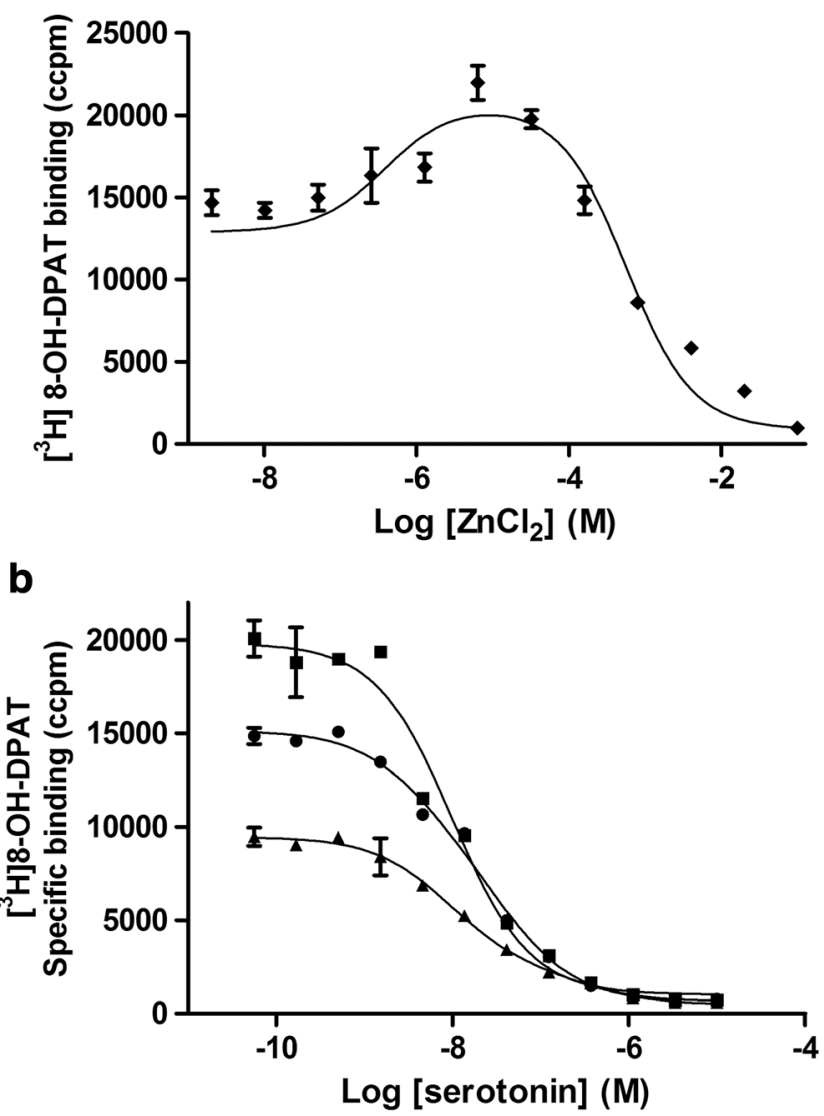

Fig. 2 The 'bell-shaped' Zn titration curve obtained in the competitionlike experiments, with the enhancement $(\sim 10 \mu \mathrm{M}$ of $\mathrm{Zn})$ and inhibition (above $100 \mu \mathrm{M}$ of $\mathrm{Zn}$ ) of $\left[{ }^{3} \mathrm{H}\right]-8-\mathrm{OH}-\mathrm{DPAT}$ binding at $5-\mathrm{HT}_{1 \mathrm{~A}} \mathrm{Rs}$. The curve was generated by fitting the data to equation 2 (a). Displacement of specific $\left[{ }^{3} \mathrm{H}\right]-8-\mathrm{OH}-\mathrm{DPAT}$ binding by 5 -HT in the absence (black circle; $K_{i}=8.7 \pm 0.6 \mathrm{nM}$ ) or presence of $10 \mu \mathrm{M}$ (black square; $K_{i}=5.4 \pm 0.2 \mathrm{nM}$; $p<0.05$ ) and $500 \mu \mathrm{M}$ (black triangle; $\left.K_{i}=8.1 \pm 0.6 \mathrm{nM}\right)$ of $\mathrm{Zn}(\mathbf{b})$

\section{Behavioural Studies}

\section{Effects of Zn Treatment on the LLR, FBP and FT in Rats}

8-OH-DPAT $(1 \mathrm{mg} / \mathrm{kg})$, the $5-\mathrm{HT}_{1 \mathrm{~A}}$ agonist, induced LLR $(p<0.001)$ in the rats. Zn, given at a dose of 2 and $5 \mathrm{mg} / \mathrm{kg}$, and WAY-100635, a 5-HT $1 \mathrm{~A}$ antagonist, given at the dose of $0.1 \mathrm{mg} / \mathrm{kg}$, did not evoke LLR; however, they blocked the LLR induced by 8-OH-DPAT ( $\mathrm{Zn}: p<0.05$ for the dose of $2 \mathrm{mg} / \mathrm{kg}$ and $p<0.001$ for the dose of $5 \mathrm{mg} / \mathrm{kg} ; p<0.01$ for WAY-100635, vs. 8-OH-DPAT) (see Table 3). When given at the doses of 2, 5, 7.5 and $11.5 \mathrm{mg} / \mathrm{kg}, \mathrm{Zn}$ did not induce FBP
Table 1 Effects of $\mathrm{Zn}^{2+}$ on $K_{D}$ and $B_{\max }$ values of $\left.{ }^{3} \mathrm{H}\right] 8-\mathrm{OH}-$ DPAT obtained in saturation binding experiments in $5-\mathrm{HT}_{1 \mathrm{~A}}$ receptors in HEK293 cells

\begin{tabular}{llllllll}
\hline $\mathrm{Zn}^{2+}[\mu \mathrm{M}]$ & 0 & 10 & 100 & 500 & 1000 & 2500 & 5000 \\
$K_{D}[\mathrm{nM}]$ & $2.9 \pm 0.1$ & $5.0 \pm 0.1$ & $6.0 \pm 0.4$ & $6.9 \pm 0.2$ & $8.2 \pm 0.9$ & $8.6 \pm 0.6$ & $9.6 \pm 0.6$ \\
$B_{\max }[\mathrm{pM} / \mathrm{mg} \operatorname{prot}]$ & $4.5 \pm 0.3$ & $5.8 \pm 0.7^{*}$ & $6.2 \pm 2.0$ & $4.7 \pm 0.7$ & $4.0 \pm 0.6$ & $3.1 \pm 1.2^{*}$ & $2.5 \pm 0.8^{*}$ \\
\hline
\end{tabular}



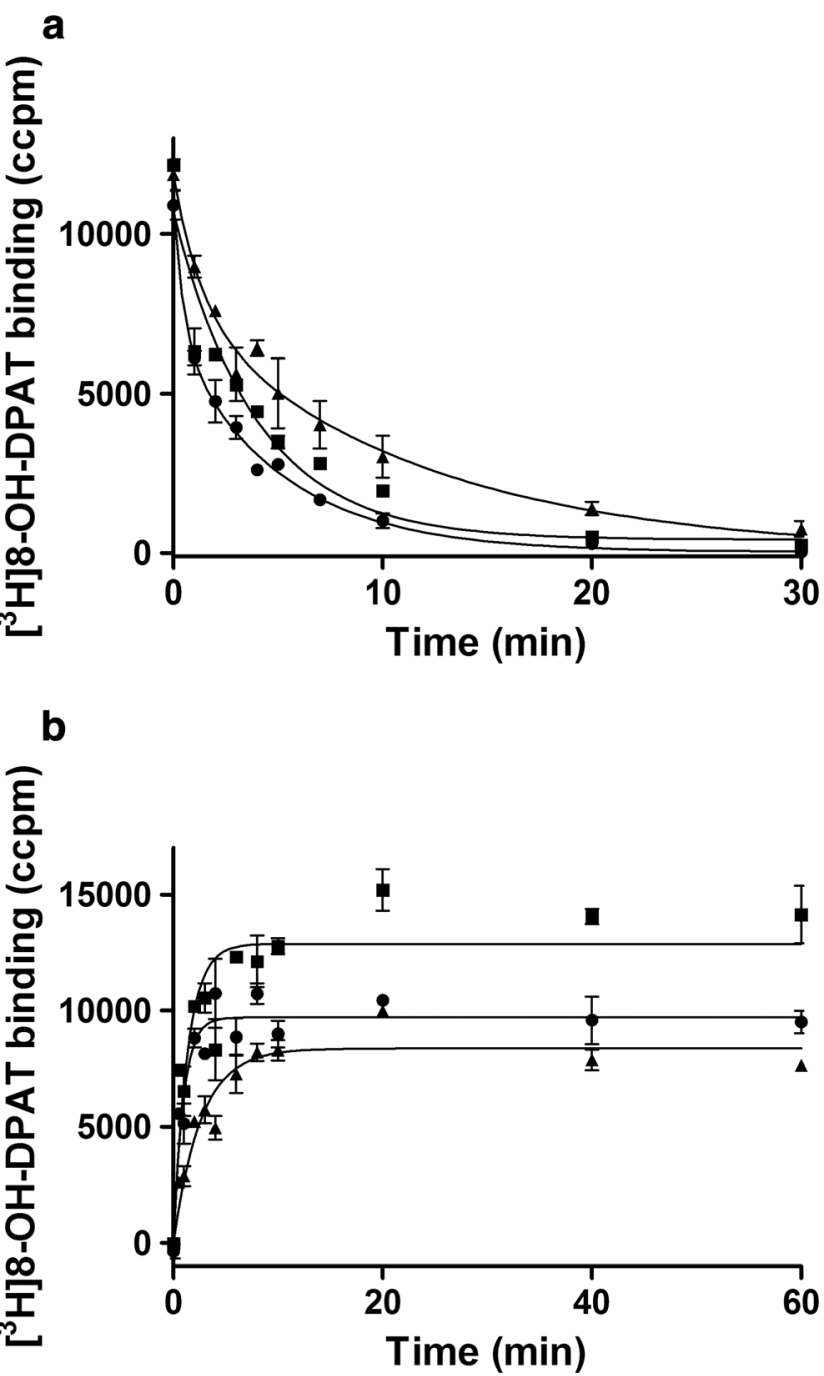

Fig. 3 Effect of $\mathrm{Zn}$ on the dissociation (a) and association (b) rates of $\left[{ }^{3} \mathrm{H}\right]-8-\mathrm{OH}-\mathrm{DPAT}$ in the absence (black circle) or presence of $10 \mu \mathrm{M}$ (black square) and $500 \mu \mathrm{M}$ (black triangle) of $\mathrm{Zn}$

or FT in the rats (see Table 4); however, at the higher doses of $11.5 \mathrm{mg} / \mathrm{kg}(p<0.001), 7.5$ and $11.5 \mathrm{mg} / \mathrm{kg}(p<0.001$ and $p<0.01$, respectively), Zn blocked the 8-OH-DPAT-induced FBP and FT.

Table 2 Association and dissociation rate constants of $\left[{ }^{3} \mathrm{H}\right]-8-\mathrm{OH}-$ DPAT obtained in the kinetic experiments in the absence and presence of Zn

\begin{tabular}{llll}
\hline & $k_{\text {on }}\left[\mathrm{M}^{-1} \mathrm{~min}^{-1}\right]$ & $k_{\text {off fast }}\left[\mathrm{min}^{-1}\right]$ & $k_{\text {off slow }}\left[\mathrm{min}^{-1}\right]$ \\
\hline Control & $3.4 \pm 0.4 \times 10^{+8}$ & $2.33 \pm 0.31$ & $0.21 \pm 0.02$ \\
$+10 \mu \mathrm{M} \mathrm{Zn}^{2+}$ & $6.4 \pm 0.8 \times 10^{+8 *}$ & $0.25 \pm 0.04^{\mathrm{a}}$ & \\
$+500 \mu \mathrm{M} \mathrm{Zn}^{2+}$ & $3.6 \pm 0.3 \times 10^{+8}$ & $0.58 \pm 0.07 * *$ & $0.06 \pm 0.02 * *$ \\
\hline
\end{tabular}

$* p<0.07 ; * * p<0.05$

a one phase
Table 3 Lower lip retraction score as a function of 8-OH-DPAT for the Zn, WAY-100635 and control groups

\begin{tabular}{lll}
\hline & \multicolumn{2}{l}{ Mean \pm LLR score } \\
\cline { 2 - 3 } Treatment $(\mathrm{mg} / \mathrm{kg})$ & (A) VEH & (B) 8-OH-DPAT 1 mg/kg \\
\hline VEH & $0.0 \pm 0.0$ & $2.25 \pm 0.46^{\# \#}$ \\
Zn 2 & $0.0 \pm 0.0$ & $1.17 \pm 0.98^{*}$ \\
Zn 5 & $0.0 \pm 0.0$ & $0.46 \pm 0.75^{* * *}$ \\
WAY 100635 0.1 & $0.0 \pm 0.0$ & $0.67 \pm 0.76^{* *}$
\end{tabular}

(A) Each animal was scored for LLR three times, 15, 30 and 45 min after the administration of $\mathrm{Zn}$ as follows: $0=$ lower incisors not visible, $0.5=$ partly visible and $1=$ completely visible. The maximum total score was 3/rat. Zn was administered at doses of 2 and $5 \mathrm{mg} \mathrm{Zn} / \mathrm{kg}$. (B) The effect of $\mathrm{Zn}$ and WAY-100635 on the LLR induced by 8-OH-DPAT was scored using the same scale. Zn and WAY-100635 was administered 45 min before 8-OH-DPAT and the animals were scored 15, 30 and 45 min after 8 -OH-DPAT treatment. The values represent the mean \pm SEM $(n=8-10$ rats per group)

${ }^{\# \# \# ~} p<0.01$ vs. VEH; $* p<0.05, * * p<0.01$ and $* * * p<0.001$ vs. $8-\mathrm{OH}-$ DPAT. Statistical analysis was performed using one-way ANOVA followed by Dunnett's post hoc test

\section{Effects of Zn Treatment on the Body Temperature of Rats and Mice}

As shown in Fig. 4, 8-OH-DPAT ( $5 \mathrm{mg} / \mathrm{kg}$ ) induced a significant decrease in body temperature of the mice (Fig. 4a) and in rats (Fig. 4b) compared to saline group $(p<0.001)$. Similarly to 8-OH-DPAT, $\mathrm{Zn}$ significantly and dose-dependently decreased body temperature of the mice at both $30(p<0.01)$ and $60 \mathrm{~min}(p<0.01)$ after administration (Fig. 4a). Zn also significantly decreased the body temperature of the rats, at both $30 \mathrm{~min}(p<0.01$ for the dose of $11.5 \mathrm{mg} / \mathrm{kg}$, and $p<0.05$ for the dose of $7.5 \mathrm{mg} / \mathrm{kg}$ ) and $60 \mathrm{~min}$ after the injection ( $p<0.01$ for the dose of $11.5 \mathrm{mg} / \mathrm{kg} ; p<0.01$ for the dose of $7.5 \mathrm{mg} / \mathrm{kg}$; and $p<0.05$ for the dose of $5 \mathrm{mg} / \mathrm{kg}$ ) (Fig. 4b).

\section{Effects of Zn Treatment on the Body Temperature} of the 5-HT $T_{1 A}$ Autoreceptor KO Mice

The effect of $\mathrm{Zn}$ treatment on the body temperature of the 5$\mathrm{HT}_{1 \mathrm{~A}}$ autoreceptor KO mice was shown in Fig. 4c. There was no difference in basal body temperature between the wild-type and $5-\mathrm{HT}_{1 \mathrm{~A}}$ autoreceptor $\mathrm{KO}$ mice $(37.7 \pm 0.23$ and $37.9 \pm$ 0.19 , respectively). $\mathrm{Zn}$ administered at a dose of $5 \mathrm{mg} / \mathrm{kg}$, decreased the body temperature of the wild-type mice but not of the autoreceptor KO mice ( $p<0.05$ at $30 \mathrm{~min}$ and $p=$ 0.06 at $60 \mathrm{~min}$ ).

\section{Effect of $Z n$ in the FST}

Rats As shown in Fig. 5a, Zn administered at a dose of $2 \mathrm{mg} / \mathrm{kg}$ but not $1 \mathrm{mg} / \mathrm{kg}$ significantly decreased the 
Table 4 Induction of behavioural syndrome by $\mathrm{Zn}(\mathrm{A})$ and the effect of $\mathrm{Zn}$ on the 8-OH-DPATinduced behavioural syndrome (B)
Treatment Dose $(\mathrm{mg} / \mathrm{kg}) \quad$ Mean \pm SEM behavioural score

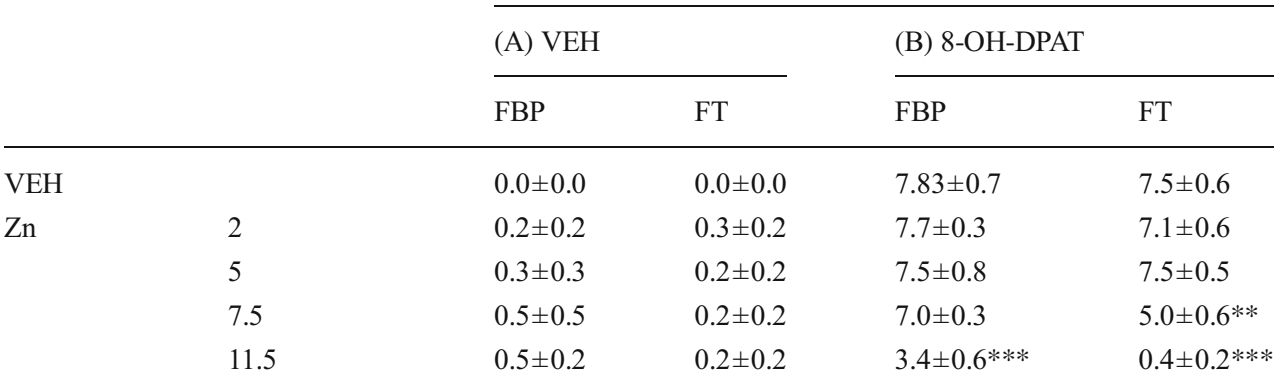

(A) In each animal, the Zn-induced behavioural syndrome was scored at 3, 6, 9, 12 and 15 min after Zn treatment. FBP, flat body posture, and FT, forepaw treading, were scored using the following scale: $0=$ absent, $1=$ equivocal, and 2 =present. The maximum score, which was summed over 5 observation periods, was 10 for each symptom/ rat. (B) The effect of $\mathrm{Zn}$ on the behavioural syndrome induced by 8-OH-DPAT was scored using the same scale. $\mathrm{Zn}$ was administered $60 \mathrm{~min}$ before 8 -OH-DPAT $(5 \mathrm{mg} / \mathrm{kg})$, and the animals were scored at 3, 6, 9, 12 and $15 \mathrm{~min}$ after 8-OH-DPAT treatment. The data represent the mean \pm SEM for $n=6$ rats

$* * * p<0.001 ; * * p<0.01$, compared to the VEH+8-OH-DPAT group. Statistical analysis was performed using one-way ANOVA followed by Dunnett's post hoc test immobility time of the rats in the FST $(p<0.01$ and $p>0.05$, respectively). 8-OH-DPAT administered at a dose of $0.3 \mathrm{mg} / \mathrm{kg}$ $(p<0.05)$ but not $0.1 \mathrm{mg} / \mathrm{kg}(p>0.05)$ decreased the immobility time of the rats in the FST. Zn given jointly with 8-OHDPATat the doses that were ineffective in the FST significantly decreased the immobility time of the rats $(p<0.01)$ compared to the VEH-treated group. As shown in Fig. 5b, Zn at a dose of 2 and $5 \mathrm{mg} / \mathrm{kg}$ significantly decreased the immobility time of the rats in the FST $(p<0.05$ and $p<0.01$, respectively). When given alone, WAY-100635, an antagonist of $5-\mathrm{HT}_{1 \mathrm{~A}} \mathrm{Rs}$ $(0.1 \mathrm{mg} / \mathrm{kg})$, did not change the behaviour of the animals in this test, but it antagonized the $\mathrm{Zn}$-induced decrease in the immobility time of the rats ( $p<0.05 \mathrm{vs}$. the $\mathrm{Zn}$-treated groups).

5-HT ${ }_{1 \mathrm{~A}}$ Autoreceptor KO Mice $\mathrm{Zn}$ administered at a dose of $5 \mathrm{mg} / \mathrm{kg}$ induced a slight (30\%) decrease in the immobility time of the $5-\mathrm{HT}_{1 \mathrm{~A}}$ autoreceptor $\mathrm{KO}$ mice compared to the VEH-treated KO mice (see Fig. 6b), while in wild-type mice (see Fig. 6a), a significant decrease in immobility time after $\mathrm{Zn}$ treatment was observed $(p<0.05)$.

\section{Discussion}

\section{Receptor Binding Studies}

As an endogenous trace element, $\mathrm{Zn}$ has been suggested to act as an allosteric modulator of a number of $\mathrm{G}$ protein-coupled receptors, such as dopamine $\mathrm{D}_{1}, \mathrm{D}_{2}$ and $\mathrm{D}_{4}$; melanocortin $\mathrm{MC}_{1}$ and $\mathrm{MC}_{4} ; \alpha_{1 \mathrm{~A}}$ and $\beta_{2}$ adrenergic; $\mu, \mathrm{K}$ and $\delta$ opioid; and serotonin $5-\mathrm{HT}_{1 \mathrm{~A}}$ receptors [28]. Despite the previous identification of $\mathrm{Zn}$ ions as allosteric inhibitors of both agonists and antagonists of 5-HT ${ }_{1 \mathrm{~A}} \mathrm{Rs}$ [13], the exact mechanism of Zn's action in relation to orthosteric agonists appears complex and is not fully understood. Thus, in the present study, an extended set of in vitro radioligand binding experiments (saturation, competition-like and kinetic tests) were undertaken using $\left[{ }^{3} \mathrm{H}\right]-8-\mathrm{OH}-\mathrm{DPAT}$ as an agonist probe to further characterize the effects of $\mathrm{Zn}$ on $5-\mathrm{HT}_{1 \mathrm{~A}} \mathrm{Rs}$.

Consistent with the data presented by Barrondo and Salles for native tissue [13], the results of the current saturation experiments using stable expression of $5-\mathrm{HT}_{1 \mathrm{~A}} \mathrm{Rs}$ in HEK293 cells suggest negative allosteric modulation of $\mathrm{Zn}$ on $\left[{ }^{3} \mathrm{H}\right]-8$ OH-DPAT binding $(\alpha=0.37)$. Nevertheless, a model of negatively cooperative interactions does not account for all of the additional data obtained in the study.

At first, $\mathrm{Zn}$ tested alone in a competition-like assay with $\left[{ }^{3} \mathrm{H}\right]-8-\mathrm{OH}-\mathrm{DPAT}$ yielded a bell-shaped binding curve, with a marked increase in agonist radioligand binding at low modulator concentrations and a decrease in binding at high concentrations (Fig. 2a). This type of curve was also shown for several adenosine $A_{1}$ allosteric modulators investigated in agonist radioligand binding assays $[27,29,30]$. The results of those studies have invariably been interpreted as evidence that the investigated molecules recognize the allosteric site at low concentrations but also bind to the orthosteric site at higher concentrations, combining the two mechanisms of action: allosteric enhancement and competitive inhibition [27, 29, 30].

Interestingly, in the competition experiments, an enhancement of agonist binding to $5-\mathrm{HT}_{1 \mathrm{~A}} \mathrm{Rs}$ was evident in the presence of $10 \mu \mathrm{M}$ of $\mathrm{Zn}$ for 5-HT only, while a concentration of $500 \mu \mathrm{M}$ of $\mathrm{Zn}$ did not change the $K_{i}$ values for this orthosteric agonist. Likewise, the association kinetics of $\left[{ }^{3} \mathrm{H}\right]-8-\mathrm{OH}-$ DPAT showed small increase in association rate $\left(k_{\text {on }}\right)$ at a low $(10 \mu \mathrm{M})$ concentration of $\mathrm{Zn}$ ions (Table 2$)$, and the lack of statistically significant effects on $k_{\text {on }}$ values at a higher $\mathrm{Zn}$ concentration $(500 \mu \mathrm{M})$ was observed (Table 2, Fig. 3). However, the results of the dissociation kinetic experiments 
Fig. 4 Effect of $\mathrm{Zn}$ and 8-OHDPAT on body temperature in mice (a), rats (b) and 5- $\mathrm{HT}_{1 \mathrm{~A}}{ }^{+/+}$ (WT) and 5-HT $1 \mathrm{~A}$ autoreceptor ${ }^{-/}$ (KO) mice (c). The change in body temperature was calculated for each animal by comparing the baseline temperature to the temperature reached 30 and $60 \mathrm{~min}$ following $\mathrm{Zn}$ or 8-OHDPAT administration. WAY100635 at a dose of $0.1 \mathrm{mg} / \mathrm{kg}$ was administered (sc) $15 \mathrm{~min}$ before the $\mathrm{Zn}$ (a). The test was performed 30 and $60 \mathrm{~min}$ after injection of $\mathrm{Zn}(5 \mathrm{mg} / \mathrm{kg})$ (ip).

The data bars represent the mean \pm SEM for $n=8$ (mice); $n=5$ (WT mice) and $n=8$ (KO mice) and $n=6$ (rats) animals. $* p<0.05$; $* * p<0.01 ; * * * p<0.001$, compared to the VEH group. Statistical analysis was performed using one-way ANOVA followed by Dunnett's post hoc test (a and b) and Student's $t$ test (c) a

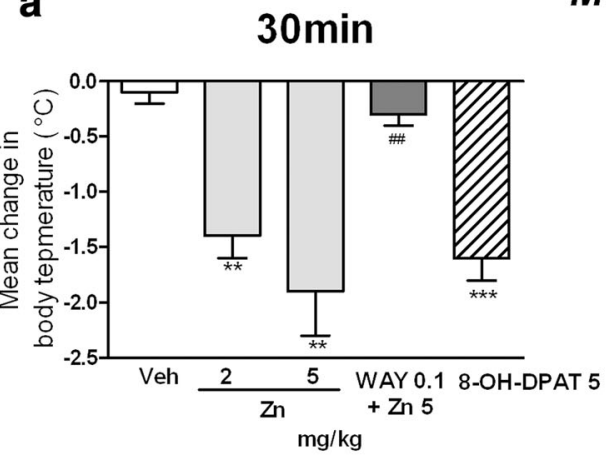

b

\section{Rats}

$30 \mathrm{~min}$

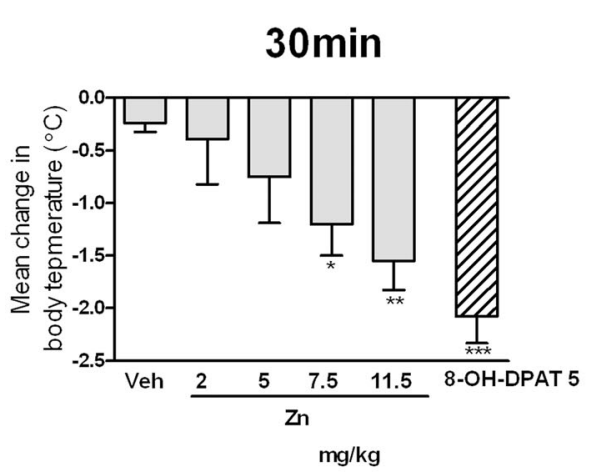

Mice

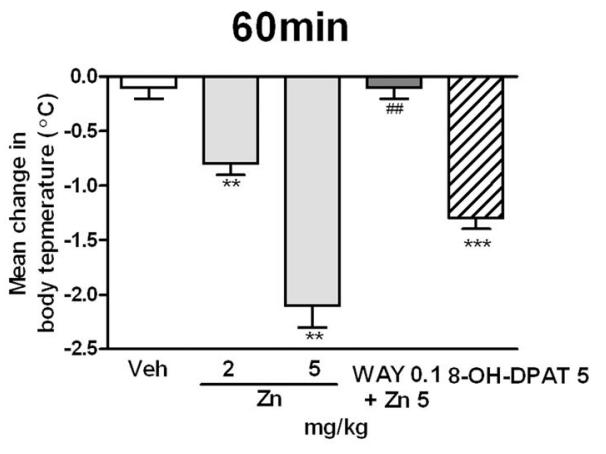

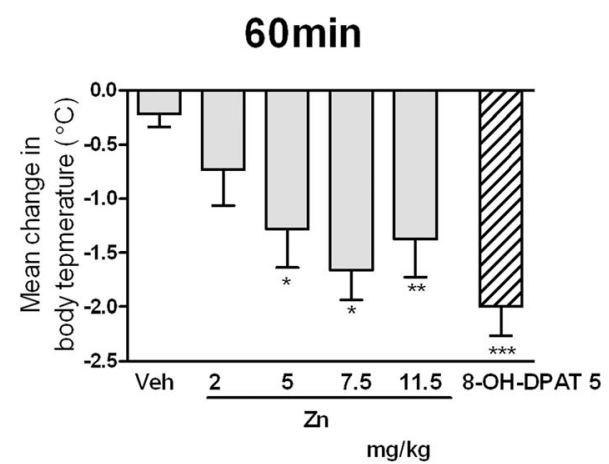

c
$30 \mathrm{~min}$

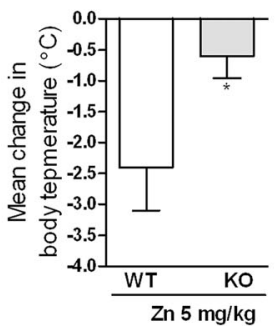

$60 \mathrm{~min}$

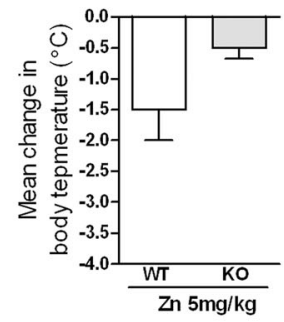

showed that both concentrations of $\mathrm{Zn}$ used slowed the radioligand dissociation rates, which is a characteristic of positive allosteric modulation (Table 2, Fig. 3).

The complex pattern of presently obtained data, when the behaviour of $\mathrm{Zn}$ in the saturation experiments and competition and kinetic assays are compared, supports the conclusion that the previously assumed negatively cooperative model is not a complete description of Zn's effects on agonist binding. Because $\mathrm{Zn}$ displayed negative cooperative interactions with $\left[{ }^{3} \mathrm{H}\right]-8-\mathrm{OH}-\mathrm{DPAT}$ in the saturation experiments but caused an increase in $B_{\max }$ values at low concentrations and directly showed properties of positive allosteric modulation in both the competition-like and kinetic experiments, a dual mode of $\mathrm{Zn}$ action against agonist binding at $5-\mathrm{HT}_{1 \mathrm{~A}} \mathrm{Rs}$ should be considered.
It is worth noting that in the case mentioned above, in which adenosine $A_{1}$ ligands showed positive cooperativity in interactions with agonists, when the same modulators were tested against antagonist probes, they were characterized only by inhibitory properties $[29,30]$. Similar probe dependence can be observed by comparing the data we obtained for the effects of $\mathrm{Zn}$ on agonist binding at 5- $\mathrm{HT}_{1 \mathrm{~A}} \mathrm{Rs}$ with earlier results describing clear negative modulation of antagonist ([3H]-WAY-100635) binding [13].

It should be mentioned that a complex mechanism of $\mathrm{Zn}$ action has also been detected for several other proteins. In electrophysiological studies of $5-\mathrm{HT}_{3}$ receptor, low concentrations of $\mathrm{Zn}(0.3-10 \mu \mathrm{M})$ enhanced and high concentrations of Zn (30-200 $\mu \mathrm{M})$ depressed, the 5-HT-induced response [31]. Biphasic effects involving potentiation at sub-micromolar and 

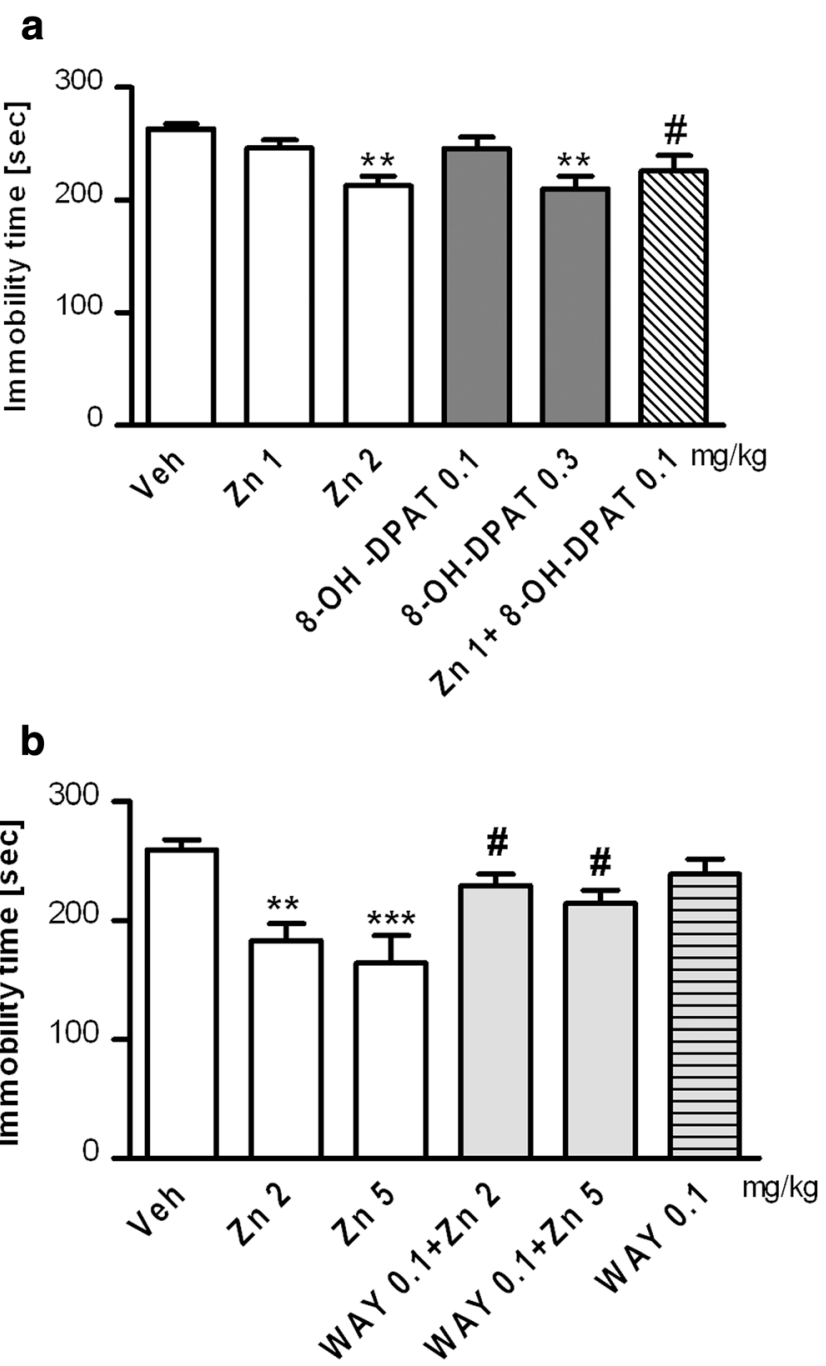

Fig. 5 Effect of $\mathrm{Zn}$ and 8-OH-DPAT given alone and jointly using the doses that did not affect immobility time in the FST in rats (a) and the effect of pretreatment with WAY-100635 on Zn-induced reduction in immobility time (b). Zn and 8-OH-DPAT were administered alone or jointly $30 \mathrm{~min}$ before the FST (a). WAY-100635 was administered $15 \mathrm{~min}$ before the $\mathrm{Zn}$ treatment, and the FST test was performed 30 min after $\mathrm{Zn}$ treatment (b). The values represent the mean $\pm \mathrm{SEM}$ ( $n=5-8$ rats). $* p<0.05 ; * * p<0.01$ vs. the VEH group; ${ }^{*} p<0.05$ vs. the $\mathrm{Zn}$ treatment group. Statistical analysis was performed using one-way ANOVA followed by Dunnett's post hoc test inhibition at sub-millimolar $\mathrm{Zn}$ concentrations have been detected for glycine receptors [32]. Similar effects were also demonstrated for $\beta_{2}$ adrenergic receptors, in which the presence of $5 \mu \mathrm{M}$ of $\mathrm{Zn}$ enhanced agonist affinity, whereas $500 \mu \mathrm{M}$ of $\mathrm{Zn}$ inhibited antagonist binding [33].

Summing up, Zn released into synaptic space from neuronal vesicles (of mostly glutamatergic terminals) was found to act at various channels and membrane receptors and these modulatory effects of $\mathrm{Zn}$ can be positive or negative depending on its concentration. The exact amount of $\mathrm{Zn}$ release is controversial; however, many laboratories have indicated that $\mathrm{Zn}$ increases in the extracellular space may reach $1-100 \mu \mathrm{M}$ [34-36]. Therefore, it seems that the effects observed at lower $\mathrm{Zn}$ concentrations should be physiologically more relevant, especially that the elevation of extracellular $\mathrm{Zn}$ level, over $300 \mu \mathrm{M}$, is reported as neurotoxic [37].

\section{In Vivo Studies}

The results of in vivo studies provide evidence that $\mathrm{Zn}$ is likely to have both an agonist and antagonist profile at $5-\mathrm{HT}_{1 \mathrm{~A}}$ receptors that could be a consequence of dual $\mathrm{Zn}$ effects at 5 $\mathrm{HT}_{1 \mathrm{~A}}$ receptors suggested by in vitro studies.

\section{Body Temperature}

Induction of hypothermia in response to the administration of 8-OH-DPAT is one of the parameters which have been proposed as an index of $5-\mathrm{HT}_{1 \mathrm{~A}} \mathrm{R}$ autoreceptor mediated activity $[23,38]$. In our study, $\mathrm{Zn}$ decreased the body temperature in mice and the intensity of this effect was similar to that observed for 8-OH-DPAT. Furthermore, pretreatment with WAY-100635, the 5-HT ${ }_{1 \mathrm{~A}} \mathrm{R}$ antagonist, abolished the effect induced by $\mathrm{Zn}$. On the other hand, our studies using $5-\mathrm{HT}_{1 \mathrm{~A}}$ autoreceptor $\mathrm{KO}$ mice showed that lack of this receptor completely blocked the hypothermia induced by $\mathrm{Zn}$, while in wild-type littermate mice, a consistent decrease in body temperature was observed. These results are consistent with those showing that hypothermic effect of $5-\mathrm{HT}_{1 \mathrm{~A}} \mathrm{R}$ agonists in mice is mediated by presynaptic $5-\mathrm{HT}_{1 \mathrm{~A}} \mathrm{R}[38,39]$ and
Fig. 6 The effect of $\mathrm{Zn}$ treatment on the immobility time in the FST in the $5-\mathrm{HT}_{1 \mathrm{~A}}^{+++}(\mathrm{WT})(\mathbf{a})$ and 5 $\mathrm{HT}_{1 \mathrm{~A}}$ autoreceptor ${ }^{-/-}(\mathrm{KO})(\mathbf{b})$ mice. $\mathrm{Zn}$ at the dose of $5 \mathrm{mg} / \mathrm{kg}$ was administered $30 \mathrm{~min}$ before the FST. The data bars represent the mean \pm SEM for $n=3-5$ mice. $* p<0.05$ compared to the VEH group. Statistical analysis was performed using Student's $t$ test a

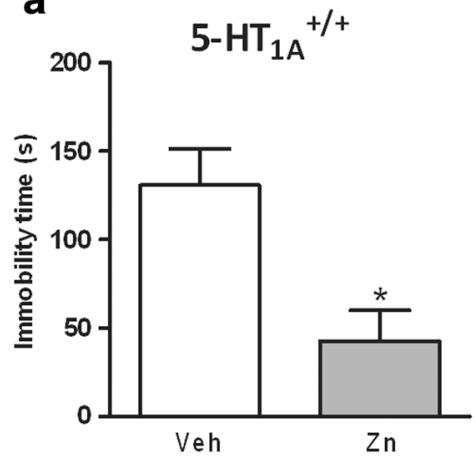

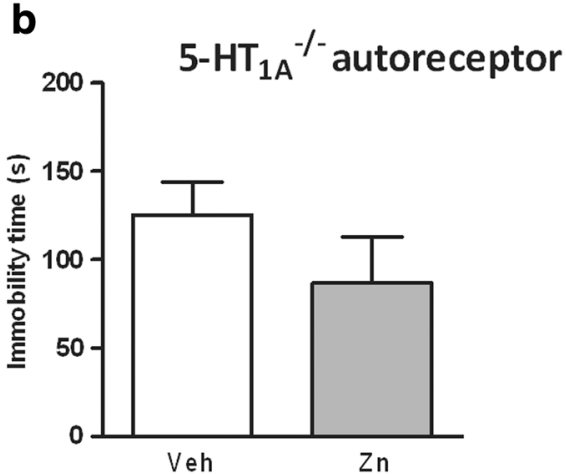


indicate an agonist-like profile of $\mathrm{Zn}$ at presynaptic 5$\mathrm{HT}_{1 \mathrm{~A}} \mathrm{Rs}$, perhaps enhancing the action of endogenous 5-HT.

In the present studies, we found that $\mathrm{Zn}$ can also induce hypothermia in rats; however, this effect was observed at higher doses than in mice. It is still controversial which 5$\mathrm{HT}_{1 \mathrm{~A}} \mathrm{Rs}$ namely pre- or postsynaptic are responsible for the induction of decrease in the body temperature in rats. Some data $[23,40,41]$ suggest that postsynaptic rather than presynaptic $5-\mathrm{HT}_{1 \mathrm{~A}} \mathrm{R}$ is implicated in this effect in rats. Despite that these data further suggest the agonist-like profile of $\mathrm{Zn}$ at 5$\mathrm{HT}_{1 \mathrm{~A}} \mathrm{R}$ as in mice.

\section{Lower Lip Retraction and 5-HT Syndrome}

Another behavioural approach used to characterize 5$\mathrm{HT}_{1 \mathrm{~A}} \mathrm{R}$ mediated activity is the induction of lower lip retraction (LLR). As shown by Berendsen et al. [20, 21], LLR was induced by the 8-OH-DPAT, buspirone, ipsapirone-agonists or partial agonists with a high affinity for $5-\mathrm{HT}_{1 \mathrm{~A}}$ binding sites in rat brain but not by serotonergic agents such as 5-MeO-DMT, mCPP or DOI with weaker affinity for $5-\mathrm{HT}_{1 \mathrm{~A}} \mathrm{R}$ but with high affinity for $5-\mathrm{HT}_{2 \mathrm{~A}} \mathrm{R}, 5-\mathrm{HT}_{2 \mathrm{~B} / 2 \mathrm{C}} \mathrm{R}$ or $5-\mathrm{HT}_{2 \mathrm{~A} / 2 \mathrm{C}} \mathrm{R}$, respectively $[20,21]$. The effect induced by $8-\mathrm{OH}-\mathrm{DPAT}$ was attenuated by $5-\mathrm{HT}_{1 \mathrm{~A}}$ antagonists such as WAY-100135 or WAY-100635 (which by themselves did not produce the LLR [42]), as well as by the above-mentioned nonselective serotonergic agents of moderate $5-\mathrm{HT}_{1 \mathrm{~A}} \mathrm{R}$ affinity which can act as antagonists of $5-\mathrm{HT}_{1 \mathrm{~A}} \mathrm{R}$. In the case of location of receptors mediating this effect, it is suggested that LLR produced by the selective $5-\mathrm{HT}_{1 \mathrm{~A}} \mathrm{R}$ agonists has been attributed to autoreceptor activation [20, 21].

In our study, Zn did not induce LLR but significantly and dose-dependently blocked the LLR induced by 8-OH-DPAT. As was mentioned above, the LLR is specific only for compounds with high efficacy at $5-\mathrm{HT}_{1 \mathrm{~A}} \mathrm{Rs}$; thus, the lack of this effect after $\mathrm{Zn}$ treatment with simultaneous blockade of 8-OHDPAT action might result from the fact that $\mathrm{Zn}$, like 5-MeODMT, mCPP or DOI, can also modulate other types of serotonin receptors, especially from $5-\mathrm{HT}_{2} \mathrm{R}$ family. It was, for instance, found that chronic $\mathrm{Zn}$ administration increased the density of 5- $\mathrm{HT}_{2 \mathrm{~A}}$ serotonin receptors in the frontal cortex [9]. Moreover, ritanserin, the $5-\mathrm{HT}_{2 \mathrm{~A} / \mathrm{C}}$ receptor antagonist, blocked the antidepressant-like effect of $\mathrm{Zn}$ in the FST [10].

Another behavioural effect induced by $5-\mathrm{HT}_{1 \mathrm{~A}} \mathrm{R}$ agonists is serotonin syndrome that is believed to reflect postsynaptic 5- $\mathrm{HT}_{1 \mathrm{~A}} \mathrm{R}$ activation. It is observed after higher doses of 8-OHDPAT and is associated with the enhanced 5-HT synthesis [43]. In the behavioural syndrome tests, $\mathrm{Zn}$ given alone did not evoke flat body posture or forepaw trading, however, in the higher doses strongly inhibited both FBP and FT showing a postsynaptic 5- $\mathrm{HT}_{1 \mathrm{~A}} \mathrm{R}$ antagonist-like profile.
Taken together, our data suggest that $\mathrm{Zn}$ has concentrationdependent actions in the above-mentioned behavioural responses that are mediated by $5-\mathrm{HT}_{1 \mathrm{~A}} \mathrm{Rs}$. Thus, LLR and hypothermia are produced following administration of low doses of $\mathrm{Zn}$ or 8-OH-DPAT and are attributed selectively to autoreceptor activation. Interestingly, $\mathrm{Zn}$ induced hypothermia in mice at lower doses than in rats. Higher doses of $\mathrm{Zn}$ were needed to reverse 8-OH-DPAT induced LLR, and only higher doses of $\mathrm{Zn}$ blocked 8-OH-DPAT induced FBP/FT. These results are consistent with a potentiating effect of $\mathrm{Zn}$ on agonist actions at $5-\mathrm{HT}_{1 \mathrm{~A}} \mathrm{R}$ at low doses and an antagonist effect at higher doses, although the absolute dose depends on the animal model and behaviour studied.

\section{Forced Swim Test}

The 5-HT ${ }_{1 \mathrm{~A}} \mathrm{R}$ agonist 8-OH-DPAT and several others serotonin agonists with varying degrees of selectivity for different subtypes of 5-HTRs produce antidepressant-like behaviour in the FST. Wieland and Lucki, [44] showed that p-chlorophenylalanine (pCPA), which is known to reduce the concentration of serotonin in the brain by inhibiting its biosynthesis, did not block the antidepressant effect of 8-OH-DPAT in the FST in rats. These and other studies suggest that the antidepressant-like effects of $5-\mathrm{HT}_{1 \mathrm{~A}} \mathrm{R}$ agonists are mediated by postsynaptic 5$\mathrm{HT}_{1 \mathrm{~A}} \mathrm{Rs}[19,44]$.

$\mathrm{Zn}$ also induces antidepressant-like effects in the FST both in rats and mice [10, 45-48]. Our earlier studies performed in mice [10] and the present studies in rats indicated that pretreatment with WAY-100635 blocked the effect of Zn. Furthermore, when $\mathrm{Zn}$ was given together with 8-OH-DPAT at the doses that were ineffective in the FST, it decreased immobility time, which suggests the additive effect of both compounds in this test and the agonist-like effect of $\mathrm{Zn}$ in the FST. Interestingly, the results of the $5-\mathrm{HT}_{1 \mathrm{~A}}$ autoreceptor $\mathrm{KO}$ mice in the FST demonstrated that the lack of presynaptic $5-\mathrm{HT}_{1 \mathrm{~A}} \mathrm{Rs}$ only partially blocked the anti-immobility effect induced by $\mathrm{Zn}$ in mice; however, pCPA pretreatment completely blocked the antidepressant-like effect of $\mathrm{Zn}$ in mice [10]. These data suggests that presynaptic receptors may be also implicated in the $\mathrm{Zn}$-induced effects in the FST. These results also showed that $\mathrm{Zn}$ does not work without endogenous serotonin, which can be attributed to its allosteric mechanism of $5-\mathrm{HT}_{1 \mathrm{~A}} \mathrm{R}$ regulation because allosteric modulators may act only in conjunction with physiological receptor activation. It should be noted, however, that the allosteric nature of $\mathrm{Zn}$ described previously [13], which suggests only the inhibition of both agonist and antagonist interactions at $5-\mathrm{HT}_{1 \mathrm{~A}} \mathrm{Rs}$, cannot explain the agonistic-like effects of $\mathrm{Zn}$ observed in our in vivo studies. In contrast, the current in vitro binding data, which showed characteristics of positive allosteric modulation in the presence of $10 \mu \mathrm{M}$ of $\mathrm{Zn}$ and the inhibition of agonist action at 
sub-millimolar $\mathrm{Zn}$ concentrations, are more coherent with the results observed in vivo.

\section{Conclusions}

In summary, our studies provide new data regarding the dual mechanism of $\mathrm{Zn}$ action at 5- $\mathrm{HT}_{1 \mathrm{~A}} \mathrm{Rs}$, which may underlie its antidepressant-like effects observed in the behavioural tests. The in vitro radioligand results revealed biphasic effects, involving allosteric potentiation of agonist binding at submicromolar $\mathrm{Zn}$ concentrations and inhibition at submillimolar $\mathrm{Zn}$ concentrations. Given the therapeutic potential of $\mathrm{Zn}$, the in vitro results obtained for lower $\mathrm{Zn}$ concentration $(10 \mu \mathrm{M})$ are within the range of reported extracellular free $\mathrm{Zn}$ concentrations (1-100 $\mu \mathrm{M})$ and thus potentiating effects may be physiologically more relevant than inhibition observed using higher $\mathrm{Zn}$ concentrations at which toxic effects may be expected.

In behavioural paradigms, which are commonly used to distinguish the pharmacological profile of new compounds at $5-\mathrm{HT}_{1 \mathrm{~A}} \mathrm{R}$, both agonist and antagonist-like effects of $\mathrm{Zn}$ at $5-\mathrm{HT}_{1 \mathrm{~A}} \mathrm{Rs}$ were found, and these data are consistent with results from the in vitro radioligand studies revealing biphasic $\mathrm{Zn}$ effects at $5-\mathrm{HT}_{1 \mathrm{~A}} \mathrm{R}$, involving allosteric potentiation of agonist binding and inhibition. Taking into account results of in vivo studies with the use of wild-type and 5-HT $1 \mathrm{~A}$ autoreceptor knockout animals, it seems that $\mathrm{Zn}$ can affect both pre- and postsynaptic $5-\mathrm{HT}_{1 \mathrm{~A}} \mathrm{Rs}$. It should be, however, stressed that more studies are needed to explain this complex mechanism of antidepressant-like effect of $\mathrm{Zn}$ via modulation of serotonin system, especially that there are many controversies in the literature concerning the participation of the pre- and postsynaptic $5-\mathrm{HT}_{1 \mathrm{~A}} \mathrm{Rs}$ in the behavioural tests in rodents.

Acknowledgments This study was supported by the grants: No. 2012/ 05/N/NZ7/02110 (G.S.) and No. 2013/08/M/NZ7/00518 (B.S.) from the National Science Centre, Poland; grant No. 123426 from Canadian Institutes of Health Research (P.R.A) and partially by statutory funds of the Institute of Pharmacology, Polish Academy of Sciences in Krakow.

\footnotetext{
Authors' Contribution G.S. conducted in vitro experiments and participated in the in vitro data analysis; B.D. and A.J.B. conducted the in vitro study design and participated in the interpretation and description of the in vitro experimental data; T.L. developed and maintained the HEK293 cell line expressing 5-HT ${ }_{1 \mathrm{~A}}$ Rs; K.S., A.R. and B.P. participated in the behavioural studies; M.D. and C.L. participated in the behavioural studies using the 5-HT $\mathrm{HA}_{1 \mathrm{~A}}$ autoreceptor KO mice; K.F.T. and R.H. generated the $5-\mathrm{HT}_{1 \mathrm{~A}}$ autoreceptor $\mathrm{KO}$ mice; P.R.A. and B.S. conceived and designed the mouse experiments; P.R.A. and G.N. contributed to the revising of the last version of the manuscript; and B.S. initiated the present studies, designed and participated in all of the behavioural studies and created the final version of the manuscript.
}

\section{Compliance with ethical standards}

Conflict of Interest The authors declare that they have no competing interests.

Open Access This article is distributed under the terms of the Creative Commons Attribution 4.0 International License (http:// creativecommons.org/licenses/by/4.0/), which permits unrestricted use, distribution, and reproduction in any medium, provided you give appropriate credit to the original author(s) and the source, provide a link to the Creative Commons license, and indicate if changes were made.

\section{References}

1. Takeda A (2000) Movement of zinc and its functional significance in the brain. Brain Res Brain Res Rev 34:137-148

2. Haase H, Maret W (2005) Fluctuations of cellular, available zinc modulate insulin signaling via inhibition of protein tyrosine phosphatases. J Trace Elem Med Biol 19:37-42

3. Smart TG, Xie X, Krishek BJ (1994) Modulation of inhibitory and excitatory amino acid receptor ion channels by zinc. Prog Neurobiol 42:393-441

4. Doboszewska U, Sowa-Kucma M, Mlyniec K, Pochwat B, Holuj M, Ostachowicz B, Pilc A, Nowak G, Szewczyk B (2015) Zinc deficiency in rats is associated with up-regulation of hippocampal NMDA receptor. Prog Neuropsychopharmacol Biol Psychiatry 56:254-263

5. Mlyniec K, Davies CL, Budziszewska B, Opoka W, Reczynski W, Sowa-Kucma M, Doboszewska U, Pilc A, Nowak G (2012) Time course of zinc deprivation-induced alterations of mice behavior in the forced swim test. Pharmacol Rep 64:567-575

6. Szewczyk B (2013) Zinc homeostasis and neurodegenerative disorders. Front Aging Neurosci 5:33

7. Siwek M, Dudek D, Paul IA, Sowa-Kucma M, Zieba A, Popik P, Pilc A, Nowak G (2009) Zinc supplementation augments efficacy of imipramine in treatment resistant patients: a double blind, placebo-controlled study. J Affect Disord 118:187-195

8. Siwek M, Dudek D, Schlegel-Zawadzka M, Morawska A, Piekoszewski W, Opoka W, Zieba A, Pilc A, Popik P, Nowak G (2010) Serum zinc level in depressed patients during zinc supplementation of imipramine treatment. J Affect Disord 126:447-452

9. Cichy A, Sowa-Kucma M, Legutko B, Pomierny-Chamiolo L, Siwek A, Piotrowska A, Szewczyk B, Poleszak E, Pilc A, Nowak G (2009) Zinc-induced adaptive changes in NMDA/glutamatergic and serotonergic receptors. Pharmacol Rep 61:1184-1191

10. Szewczyk B, Poleszak E, Wlaz P, Wrobel A, Blicharska E, Cichy A, Dybala M, Siwek A, Pomierny-Chamiolo L, Piotrowska A, Branski P, Pilc A, Nowak G (2009) The involvement of serotonergic system in the antidepressant effect of zinc in the forced swim test. Prog Neuropsychopharmacol Biol Psychiatry 33:323-329

11. Detke MJ, Rickels M, Lucki I (1995) Active behaviors in the rat forced swimming test differentially produced by serotonergic and noradrenergic antidepressants. Psychopharmacology (Berl) 121:66-72

12. Tena-Campos M, Ramon E, Lupala CS, Perez JJ, Koch KW, Garriga P (2015) Zinc is involved in depression by modulating G protein-coupled receptor heterodimerization. Mol Neurobiol.

13. Barrondo S, Salles J (2009) Allosteric modulation of 5-HT(1A) receptors by zinc: binding studies. Neuropharmacology 56:455-462

14. Heusler P, Rauly-Lestienne I, Tourette A, Tardif S, Ailhaud MC, Croville G, Cussac D (2010) Actions of the prototypical 5-HT1A receptor agonist 8-OH-DPAT at human alpha2-adrenoceptors: (+)8- 
OH-DPAT, but not (-)8-OH-DPAT is an alpha2B subtype preferential agonist. Eur J Pharmacol 640:8-14

15. Shen Y, Monsma FJ Jr, Metcalf MA, Jose PA, Hamblin MW, Sibley DR (1993) Molecular cloning and expression of a 5-hydroxytryptamine7 serotonin receptor subtype. J Biol Chem 268:18200-18204

16. Christopoulos A, Kenakin T (2002) G protein-coupled receptor allosterism and complexing. Pharmacol Rev 54:323-374

17. Albert PR, Vahid-Ansari F, Luckhart C (2014) Serotonin-prefrontal cortical circuitry in anxiety and depression phenotypes: pivotal role of pre- and post-synaptic 5-HT1A receptor expression. Front Behav Neurosci 8:199

18. Santana N, Bortolozzi A, Serrats J, Mengod G, Artigas F (2004) Expression of serotonin1 A and serotonin2A receptors in pyramidal and GABAergic neurons of the rat prefrontal cortex. Cereb Cortex 14:1100-1109

19. Assie MB, Bardin L, Auclair AL, Carilla-Durand E, Depoortere R, Koek W, Kleven MS, Colpaert F, Vacher B, Newman-Tancredi A (2010) F15599, a highly selective post-synaptic 5-HT(1A) receptor agonist: in-vivo profile in behavioural models of antidepressant and serotonergic activity. Int J Neuropsychopharmacol 13:1285-1298

20. Berendsen HH, Jenck F, Broekkamp CL (1989) Selective activation of 5HT1A receptors induces lower lip retraction in the rat. Pharmacol Biochem Behav 33:821-827

21. Berendsen HH, Bourgondien FG, Broekkamp CL (1994) Role of dorsal and median raphe nuclei in lower lip retraction in rats. Eur J Pharmacol 263:315-318

22. Cryan JF, Kelliher P, Kelly JP, Leonard BE (1999) Comparative effects of serotonergic agonists with varying efficacy at the 5HT(1A) receptor on core body temperature: modification by the selective 5-HT(1A) receptor antagonist WAY 100635. J Psychopharmacol 13:278-283

23. Millan MJ, Rivet JM, Canton H, Le Marouille-Girardon S, Gobert A (1993) Induction of hypothermia as a model of 5hydroxytryptamine $1 \mathrm{~A}$ receptor-mediated activity in the rat: a pharmacological characterization of the actions of novel agonists and antagonists. J Pharmacol Exp Ther 264:1364-1376

24. Leach K, Sexton PM, Christopoulos A (2011) Quantification of allosteric interactions at $\mathrm{G}$ protein-coupled receptors using radioligand binding assays. Curr Protoc Pharmacol 52:1.22.1-1.22.41

25. Samuels BA, Anacker C, Hu A, Levinstein MR, Pickenhagen A, Tsetsenis T, Madronal N, Donaldson ZR, Drew LJ, Dranovsky A, Gross CT, Tanaka KF, Hen R (2015) 5-HT1A receptors on mature dentate gyrus granule cells are critical for the antidepressant response. Nat Neurosci 18:1606-1616

26. Paluchowska MH, Mokrosz MJ, Bojarski A, Wesolowska A, Borycz J, Charakchieva-Minol S, Chojnacka-Wojcik E (1999) On the bioactive conformation of NAN-190 (1) and MP3022 (2), 5HT(1A) receptor antagonists. J Med Chem 42:4952-4960

27. Gregory KJ, Sexton PM, Christopoulos A (2010) Overview of receptor allosterism. Curr Protoc Pharmacol Chapter 1:Unit 1.21. doi: 10.1002/0471141755.ph0121s51

28. van der Westhuizen ET, Valant C, Sexton PM, Christopoulos A (2015) Endogenous allosteric modulators of G protein-coupled receptors. J Pharmacol Exp Ther 353:246-260

29. Bruns RF, Fergus JH (1990) Allosteric enhancement of adenosine A1 receptor binding and function by 2-amino-3-benzoylthiophenes. Mol Pharmacol 38:939-949

30. Valant C, Aurelio L, Urmaliya VB, White P, Scammells PJ, Sexton PM, Christopoulos A (2010) Delineating the mode of action of adenosine A1 receptor allosteric modulators. Mol Pharmacol 78:444-455
31. Gill CH, Peters JA, Lambert JJ (1995) An electrophysiological investigation of the properties of a murine recombinant 5-HT3 receptor stably expressed in HEK 293 cells. Br J Pharmacol 114:1211-1221

32. Maksay G, Biro T (2002) Dual cooperative allosteric modulation of binding to ionotropic glycine receptors. Neuropharmacology 43 : 1087-1098

33. Swaminath G, Steenhuis J, Kobilka B, Lee TW (2002) Allosteric modulation of beta2-adrenergic receptor by $\mathrm{Zn}(2+)$. Mol Pharmacol 61:65-72

34. Maret W (2013) Zinc biochemistry: from a single zinc enzyme to a key element of life. Adv Nutr 4:82-91

35. Qian J, Noebels JL (2005) Visualization of transmitter release with zinc fluorescence detection at the mouse hippocampal mossy fibre synapse. J Physiol 566:747-758

36. Sensi SL, Paoletti P, Koh JY, Aizenman E, Bush AI, Hershfinkel M (2011) The neurophysiology and pathology of brain zinc. J Neurosci 31:16076-16085

37. Plum LM, Rink L, Haase H (2010) The essential toxin: impact of zinc on human health. Int J Environ Res Public Health 7:13421365

38. Bill DJ, Knight M, Forster EA, Fletcher A (1991) Direct evidence for an important species difference in the mechanism of 8-OHDPAT-induced hypothermia. Br J Pharmacol 103:1857-1864

39. Richardson-Jones JW, Craige CP, Guiard BP, Stephen A, Metzger KL, Kung HF, Gardier AM, Dranovsky A, David DJ, Beck SG, Hen R, Leonardo ED (2010) 5-HT1A autoreceptor levels determine vulnerability to stress and response to antidepressants. Neuron 65 : 40-52

40. Bagdy G, To CT (1997) Comparison of relative potencies of i.v. and i.c.v. administered 8-OH-DPAT gives evidence of different sites of action for hypothermia, lower lip retraction and tail flicks. Eur J Pharmacol 323:53-58

41. Schenk S, Abraham B, Aronsen D, Colussi-Mas J, Do J (2013) Effects of repeated exposure to MDMA on 5HT1a autoreceptor function: behavioral and neurochemical responses to 8-OHDPAT. Psychopharmacology (Berl) 227:355-361

42. Przegalinski E, Filip M, Budziszewska B, Chojnacka-Wojcik E (1994) Antagonism of (+)WAY 100135 to behavioral, hypothermic and corticosterone effects induced by 8-OH-DPAT. Pol J Pharmacol 46:21-27

43. Kleven M, Ybema C, Carilla E, Hamon M, Koek W (1995) Modification of behavioral effects of 8-hydroxy-2-(di-npropylamino)tetralin following chronic ethanol consumption in the rat: evidence for the involvement of 5-HT1A receptors in ethanol dependence. Eur J Pharmacol 281:219-228

44. Wieland S, Lucki I (1990) Antidepressant-like activity of 5-HT1A agonists measured with the forced swim test. Psychopharmacology (Berl) 101:497-504

45. Kroczka B, Zieba A, Dudek D, Pilc A, Nowak G (2000) Zinc exhibits an antidepressant-like effect in the forced swimming test in mice. Pol J Pharmacol 52:403-406

46. Kroczka B, Branski P, Palucha A, Pilc A, Nowak G (2001) Antidepressant-like properties of zinc in rodent forced swim test. Brain Res Bull 55:297-300

47. Szewczyk B, Poleszak E, Sowa-Kucma M, Wrobel A, Slotwinski S, Listos J, Wlaz P, Cichy A, Siwek A, Dybala M, Golembiowska K, Pilc A, Nowak G (2010) The involvement of NMDA and AMPA receptors in the mechanism of antidepressant-like action of zinc in the forced swim test. Amino Acids 39:205-217

48. Nowak G (2015) Zinc, future mono/adjunctive therapy for depression: mechanisms of antidepressant action. Pharmacol Rep 67:659-662 